\title{
Review Article \\ PPAR Gamma: Coordinating Metabolic and Immune Contributions to Female Fertility
}

\author{
Cadence E. Minge, Rebecca L. Robker, and Robert J. Norman \\ Research Centre for Reproductive Health, School of Paediatrics and Reproductive Health, The University of Adelaide, \\ South Australia 5005, Australia
}

Correspondence should be addressed to Robert J. Norman, robert.norman@adelaide.edu.au

Received 2 April 2007; Accepted 2 July 2007

Recommended by Pascal Froment

Peroxisome proliferator-activated receptor gamma (PPARG) regulates cellular functions such as adipogenesis and immune cell activation. However, new information has indicated additional roles of PPARG directing the cyclic changes that occur within ovarian tissue of female mammals, including those that facilitate the release of oocytes each estrous cycle. In addition to ovarian PPARG expression and function, many PPARG actions within adipocytes and macrophages have additional direct and indirect implications for ovarian function and female fertility. This encompasses the regulation of lipid uptake and transport, insulin sensitivity, glucose metabolism, and the regulation of inflammatory mediator synthesis and release. This review discusses the developing links between PPARG activity and female reproductive function, and highlights several mechanisms that may facilitate such a relationship.

Copyright (C) 2008 Cadence E. Minge et al. This is an open access article distributed under the Creative Commons Attribution License, which permits unrestricted use, distribution, and reproduction in any medium, provided the original work is properly cited.

\section{INTRODUCTION}

Since its initial identification in the early 1990's, peroxisome proliferator-activated receptor gamma (PPARG) has been primarily recognised as a regulator of cellular functions such as adipogenesis and immune cell activation. However, some recent reviews have discussed additional roles of PPARG directing the cyclic changes that occur within ovarian tissue of female mammals, including those that facilitate the release of oocytes each estrous cycle [1-4]. In addition to ovarian PPARG expression and function, many PPARG actions within adipocytes and macrophages have additional direct and indirect implications for ovarian function and female fertility. For instance, PPARG, through activation by thiazolidinediones (TZDs), is known to regulate the metabolism of lipids, providing both self-regulatory PPARG transcriptional mechanisms, and stimulating an increase in adipogenesis. Whilst the net volume of adipose tissue carried within an individual can influence reproductive potential, genes associated with lipid metabolism are also important for ovarian cells directly. As a result, PPARG has the potential to influence the cellular operations of follicles contain- ing oocytes and, consequently, the health of those oocytes released. Likewise, the PPARG regulation of insulin sensitivity, downstream signalling pathways, and ultimately glucose uptake are likely to be also vitally important for normal ovarian function and overall female fertility.

Similarly, PPARG regulation of macrophage function has been addressed in vitro and within the context of the adipose tissue for many years; but appropriate activity of resident immune cells is also a prerequisite for normal ovarian function, as they are required for tissue remodelling facilitating ovulation, luteinization, and luteolysis [5]. Therefore, not only are adipose/circulating macrophage-sourced inflammatory mediators sensed by ovarian cells, but these mediators, when produced locally by the ovary, may influence the ovarian function in an autocrine fashion.

This review aims to provide evidence for how PPARGregulated pathways influence the female's ability to produce healthy, developmentally competent oocytes. This is impacted by cellular function operating primarily at the local ovarian level, either directly acting upon the oocyte itself, or influencing the supporting ovarian cells that supply the oocyte with hormonal signals and nutrients. In addition, 


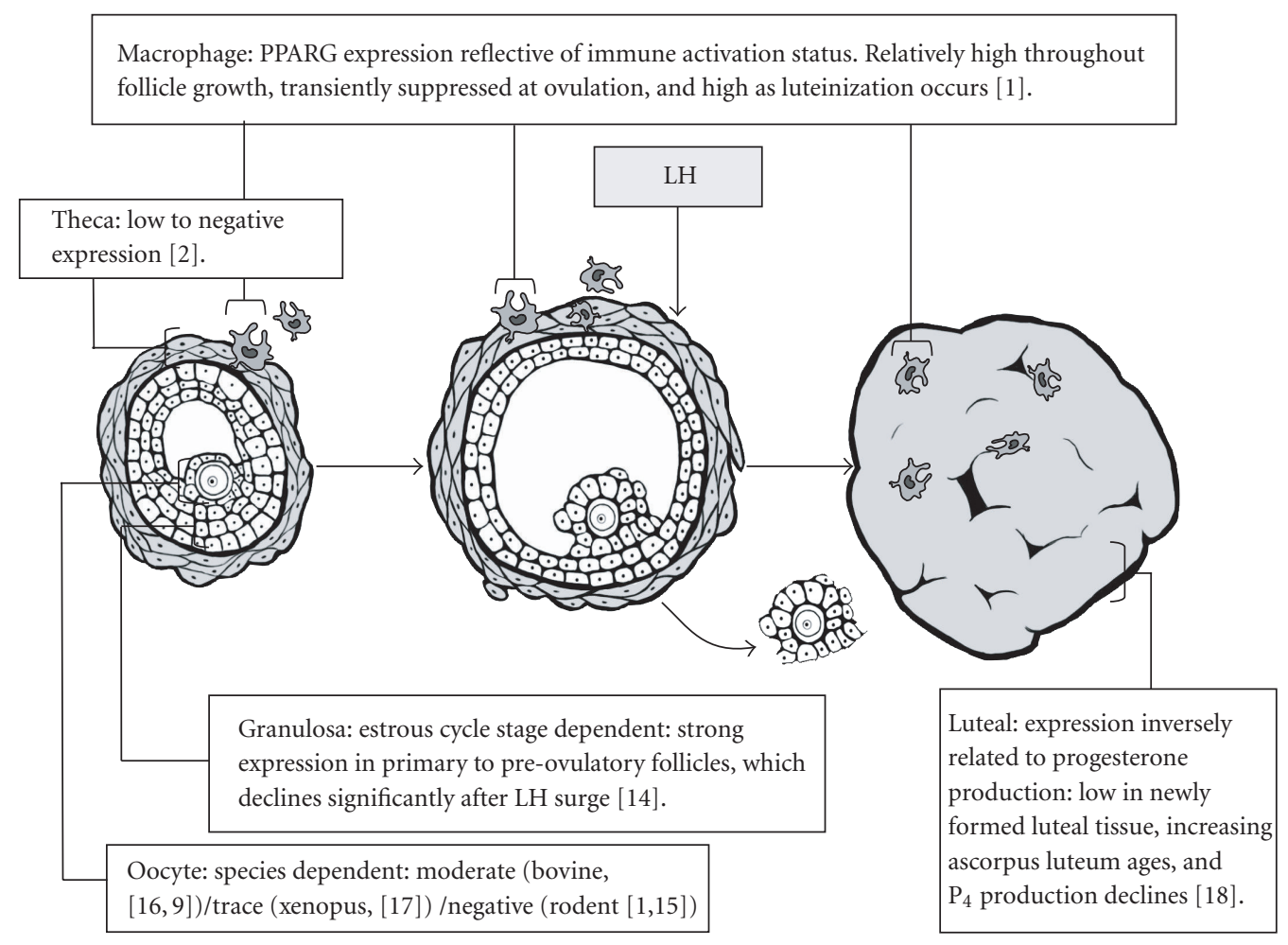

Figure 1: Overview of PPARG expression by specific ovarian cell types, as follicular development progresses from early antral and preovulatory follicle to postovulatory corpus luteum.

signals from extraovarian tissues, in particular adipose tissue and the circulating and/or resident immune cells, also exert powerful influences over the normal function of the ovary.

These concepts of overlapping influence on female fertility are particularly important when we consider conditions of reduced and impaired fertility such as polycystic ovary syndrome (PCOS), as well as reduction of reproductive function associated with excessive bodyweight and insulin resistance. In these situations, profound dysregulation of both metabolic and immune signalling pathways exacerbate ovarian perturbations, which are often successfully treated with administration of PPARG-activating pharmaceuticals.

\section{PPARG GENE EXPRESSION}

Successful mammalian reproduction requires a female body adequately, but not excessively, nourished, equipped to produce healthy eggs and to supply a growing fetus with sufficient energy. In this way, many tissues within the female body are able to influence the level of fertility. The extent of PPARG expression and its temporal regulation within these tissues can provide an interesting insight into the role of PPARG in female fertility.

\subsection{Ovarian PPARG}

Within the ovary, processes that are modulated by the PPAR superfamily, particularly PPARG, are among the most critical to normal ovarian function (Figure 1). Steroidogenesis, tissue remodelling, angiogenesis, lipid metabolism, immune cell activation, and production of proinflammatory mediators are all, to some extent, controlled by the presence and activity of the PPAR nuclear receptors. All three PPAR isotypes have been identified in the ovary of many species including the rat $[2,6]$, mouse [7], pig [8], sheep [9], cow $[10,11]$, and human $[12,13]$. Localisation of these nuclear receptors has been established by both in situ hybridisation and immunohistochemistry [6]. Transcripts for PPAR alpha (PPARA) have been identified in immune cells and cells in the theca and stroma, whilst PPAR delta (PPARD) is found across all ovarian compartments [2]. Ovarian expression of both PPARA and PPARD is relatively stable across the ovulatory cycle, which suggests these isotypes are likely involved in regulating basal ovarian functions. PPARG is expressed strongly in the granulosa cells (primarily responsible for both estradiol production and the regulation of follicular fluid content), and lessstrongly in the thecalregion (site of androgen precursor production for granulosa estradiol synthesis) and luteal cells (postovulatory progesterone production) in the ovaries of rodents and ruminants $[1,2,9,14]$. PPARG is detected earlyin folliculogenesis, and in contrast to PPARA and PPARD isotypes, its expression is dynamic, increasing until the large folliclestage [9], followed by downregulation in response to the LH surge [2].

Within the oocyte itself, PPARG expression seems to be dependent upon species, as moderate expression has been reported in ruminants [16], trace levels in Xenopus oocytes [17], and undetectable expression in rodents $[1,18]$. It has not yet been investigated within the human oocyte. 


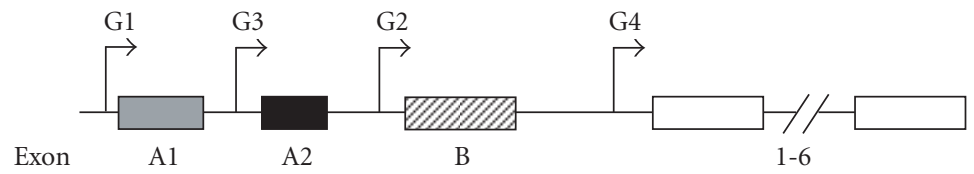

(a)

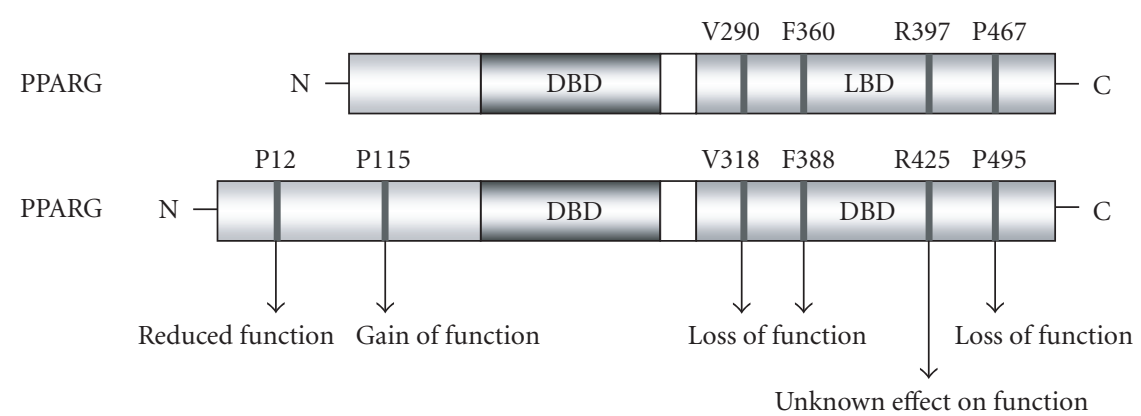

(b)

Figure 2: (a) The genomic structure of the 5' end of the human PPARG gene. Exons 1-6 are common. Exons A1 and A2 are untranslated, and exon B is translated, giving rise to two different proteins corresponding to the G1 or G2 transcripts. (b) The domain structure of PPARG1 and G2 isoforms with the positioning of mutations or polymorphisms resulting in substituted amino acid residues, and altered protein functions. DBD, DNA-binding domain; LBD, Ligand-binding domain. (Figure adapted from Sundvold and Lien[33], Tsai and Maeda [37], and Stumvoll and Häring [38]).

\subsection{Extraovarian PPARG}

The highest level of mammalian PPARG expression is found within adipose tissue $[19,20]$, and activation of this adipose PPARG is sufficient [21] and essential to induce adipogenesis $[22,23]$. Adiposity is also a key regulator of female fertility, affecting multiple aspects of the reproductive axis in women $[24,25]$. Many of the adipocyte-sourced factors that are under PPARG control, such as the production of nonesterified free fatty acids, have widespread effects including ovarian targets [26-28]. In addition, any activation of adipose PPARG that may influence the amount and activity of adipocytes/adipokines can subsequently impact upon reproductive potential [29].

Both the ovary and adipose tissue are comprised of a considerable proportion of immune cells, in particular macrophages. Macrophages recruited into tissues are an important source of many inflammatory mediators that have functions both locally and systemically. Within the ovary, macrophage contribution to the pool of functional PPARG has been assessed [1]. TZD treatment has also been found to affect adipose-recruited macrophages, by increasing the rate of apoptosis, providing a subsequent reduction in the number of proinflammatory cytokine-producing cells [30]. Improvements to the chronically inflamed profile of women with PCOS may well go some way in explaining the beneficial systemic effects of PPARG activation in such patients (see Sections 3.2 and 4.4).

\subsection{Mutations in PPARG negatively influence female fertility}

The PPARG gene contains 9 exons, and spans more than $100 \mathrm{~kb}$ [31] (Figure 2(a)). There are at least 4 isoforms of
PPARG, resulting from the use of different initiator methionines [31-33], which are believed to be involved in regulated gene expression in specific cells and tissues. PPARG1, expressed utilizing the untranslated exons A1 and A2, is 477 amino acids long, and is expressed at low levels in many tissues [34]. PPARG2 contains the translated exon B, and as a result is 28 amino acids longer than PPARG1 [35]. This isotype is expressed selectively in white adipose tissue, colonic epithelium, and macrophages [36]. PPARG3, which contains only exon A2, is found only in the large intestine and macrophages [31]. PPARG4 is limited to exon 1-6 common to all isotypes [33]. There have been numerous studies into the effects of genetic variability of PPARG gene sequence and expression, in both rodent models and human patients (Figure 2(b), Table 1).

Work initiated in rodent knockout models revealed that total $\mathrm{PPARG}^{-/-}$mutants display two independent lethal phases [23]. Firstly, PPARG deficiency interferes with terminal differentiation of the trophoblast cells and with placental vascularization, leading to myocardial thinning, and death by embryonic day 10 . When PPARG null embryos are provided with a wild-type placenta, this cardiac defect was corrected permitting delivery, although postnatal pathologies (including multiple haemorrhages and lipodystrophy) resulted in lethality. To circumvent such restrictions, the CreloxP system can be applied, where Cre recombinase was under the control of the whey acidic protein (WAP) or mouse mammary tumour virus (MMTV) promoters. This causes PPARG gene deletions specific to secretory and hematopoietic tissues (alveolar epithelial cells of mammary tissue, salivary gland cells, oocytes, granulosa cells, megakaryocytes, and $\mathrm{B}$ - and T-cells) [50]. The results of this study revealed an important PPARG role in fertility: although the mutant mice appeared to ovulate normally, they exhibited reduced 
TABLE 1: Phenotypes and reproductive effects associated with PPARG mutations in mice and humans. Abbreviations used: ART: artificial reproductive technology; BAT: brown adipose tissue; BMI: body mass index; HbA(1C): haemoglobin A1C; KO: knock-out; PCOS: polycystic ovary syndrome; T2DM: Type 2 Diabetes Mellitus; TG: Triglycerides; WAT: white adipose tissue.

\begin{tabular}{|c|c|c|c|c|}
\hline Species & $\begin{array}{l}\text { Genetic } \\
\text { Abberation }\end{array}$ & Outcome & Effect on female fertility & Reference \\
\hline \multirow{4}{*}{ Mouse } & $\begin{array}{l}\text { Global } \\
\text { PPARG }^{-/-}\end{array}$ & Neonatal death & - & {$[23]$} \\
\hline & $\begin{array}{l}\text { Global } \\
\text { PPARG }^{-/+}\end{array}$ & $\begin{array}{l}\text { Improved insulin } \\
\text { sensitivity }\end{array}$ & Fertile & {$[39]$} \\
\hline & $\begin{array}{l}\text { Mammary, } \\
\text { epithelium, } \\
\text { ovary, B- and } \\
\text { T-cell null }\end{array}$ & $\begin{array}{l}\text { Ovarian dysfunction and } \\
\text { abrogated mammary } \\
\text { development }\end{array}$ & $\begin{array}{l}30 \% \text { of animals completely } \\
\text { infertile, remainder had } \\
\text { delayed conception, } \\
\text { reduced litter size }\end{array}$ & {$[7]$} \\
\hline & $\begin{array}{l}\text { PPARG hyp/hyp: } \\
\text { WAT BAT, liver, } \\
\text { and muscle null. }\end{array}$ & $\begin{array}{l}\text { Normal birthweight but } \\
\text { subsequent growth } \\
\text { retardation, lipodystrophy, } \\
\text { hyperlipideamia, and mild } \\
\text { glucose intolerance }\end{array}$ & $\begin{array}{l}\text { Heterozygote matings } \\
\text { produce normal sized } \\
\text { litters, but homozygote } \\
\text { matings result in reduced } \\
\text { litter size. }\end{array}$ & {$[40]$} \\
\hline \multirow{7}{*}{ Human } & $\begin{array}{l}\text { Pro12Ala (34C } \\
>\text { G), PPARG2 } \\
\text { only. }\end{array}$ & $\begin{array}{l}\text { Ala allele } \downarrow \text { PPREs affinity, } \\
\downarrow \text { PPARG transactivation. } \\
\uparrow \text { Insulin sensitivity in } \\
\text { some studies, conflicting } \\
\text { reports on association with } \\
\text { BMI. }\end{array}$ & $\begin{array}{l}\text { Possible relationship with } \\
\text { PCOS. In wider, non-PCOS } \\
\text { population Ala allele } \\
\text { associated with } \\
\downarrow \text { testosterone production }\end{array}$ & {$[41-43]$} \\
\hline & $\begin{array}{l}\text { Pro115Gln } \\
(344 \mathrm{G}>\mathrm{T}) \\
\text { PPARG2 only. }\end{array}$ & $\begin{array}{l}\text { Constitutively activated } \\
\text { PPARG, } \uparrow \text { adipocyte } \\
\text { differentiation. Severe } \\
\text { obesity, } 3 / 4 \text { subjects T2DM. }\end{array}$ & Fertility not assessed. & {$[44]$} \\
\hline & $\begin{array}{l}\text { His } 447 \text { His } \\
(1431 \mathrm{C}>\mathrm{T})\end{array}$ & $\begin{array}{l}\mathrm{T} \text { allele may increase } \\
\text { adipocyte differentiation. } \\
\text { Presence of T allele } \\
\text { associated with } \uparrow \mathrm{BMI} \text {, and } \\
\text { insulin sensitivity. }\end{array}$ & $\begin{array}{l}\text { T allele more common in } \\
\text { PCOS compared to } \\
\text { BMI-matched controls. T } \\
\text { allele associated with } \\
\downarrow \text { testosterone. }\end{array}$ & {$[43,45]$} \\
\hline & $\begin{array}{l}\text { Pro467Leu } \\
(1647 \mathrm{C}>\mathrm{T})\end{array}$ & $\begin{array}{l}\text { Mutation in LBD, } \\
\downarrow \text { coactivator recruitment } \\
\text { and downstream } \\
\text { transactivation. } \downarrow \text { Basal } \\
\text { gene activity. } \\
\text { Lipodystrophy but normal } \\
\text { BMI, severe insulin } \\
\text { resistance and } \\
\text { hypertension. One carrier } \\
\text { (from } 4 \text { ) responsive to } \\
\text { rosiglitazone therapy. }\end{array}$ & $\begin{array}{l}\text { Oligomenorrhoea and } \\
\text { hirtsutism, required ART } \\
\text { for 1st pregnancy, } \\
\text { complicated by } \\
\text { pre-eclampsia and induced } \\
\text { labour. 2nd pregnancy } \\
\text { spontaneously conceived, } \\
\text { with pre-eclampia, preterm } \\
\text { emergency caesarean, and } \\
\text { neonatal infant death. }\end{array}$ & {$[46,47]$} \\
\hline & $\begin{array}{l}\text { Val290Met } \\
(1115 \mathrm{G}>\mathrm{A})\end{array}$ & $\begin{array}{l}\text { Mutation affects LBD, } \\
\text { profound blockage of } \\
\text { transcriptional activation. } \\
\text { Similar phenotype to } \\
\text { P467L. Unresponive to } \\
\text { rosiglitazone therapy. }\end{array}$ & $\begin{array}{l}\text { Primary amenorrhoea, } \\
\text { hirsutism, acanthosis } \\
\text { nigricans, and } \\
\text { hypertension. }\end{array}$ & {$[46,47]$} \\
\hline & $\begin{array}{l}\text { Phe388Leu } \\
(1164 \mathrm{~T}>\mathrm{A})\end{array}$ & $\begin{array}{l}\downarrow \text { PPARG-ligand binding, } \\
\downarrow \text { basal transcriptional } \\
\text { activity. Lipodystrophic } \\
\text { and hypertensive with } \\
\uparrow \text { TG. Hyperinsulinemic, } \\
\text { later T2DM. }\end{array}$ & $\begin{array}{l}\text { Irregular menses, and } \\
\text { bilateral polycystic ovaries } \\
\text { treated with } \\
\text { salpingo-oopherectomy. } \\
\text { Prior to this carried two } \\
\text { pregnancies. }\end{array}$ & {$[48]$} \\
\hline & $\begin{array}{l}\text { Arg397Cys } \\
(1273 \mathrm{C}>\mathrm{T})\end{array}$ & $\begin{array}{l}\text { Mutation in LBD, } \\
\text { unknown effect on PPARG } \\
\text { function. Lipodystrophic, } \\
\uparrow \text { TG and T2DM. }\end{array}$ & $\begin{array}{l}\text { Hirsutism but no other } \\
\text { indications of } \\
\text { hyperandrogenism. } \\
\text { Delayed menarche, but } \\
\text { regular menses. }\end{array}$ & {$[49]$} \\
\hline
\end{tabular}


progesterone secretion as well as impaired implantation. Interestingly, fertility is affected even when the lesion in PPARG expression is restricted to extraovarian sites, as homozygote matings of PPAR hyp/hyp mutants, lacking PPARG expression in white and brown adipose tissue, liver, and muscle, had reduced litter size [40].

Examinations of naturally occurring human polymorphisms have focussed on susceptibility to Type II diabetes, insulin sensitivity, and obesity, and to date at least seven polymorphisms within the PPARG gene have been described.

The Pro12Ala polymorphism is located in exon2, and is only translated within the adipose tissue-, macrophage-, and colonic epithelium-specific PPARG2 isotype. The Pro12 allele is carried by approximately $85 \%$ of certain regional populations [51], and a single nucleotide mutation $(C \rightarrow G)$ leads to the substitution of an Ala amino acid [41]. PPARG protein produced by the Ala12 allele shows reduced in vitro affinity for PPAR response elements (PPREs) in target gene proximal promoters, and subsequently has reduced PPARG transactivation [41]. This PPARG SNP was extensively studied, following initial reports that it was strongly associated with bodyweight and insulin sensitivity [41], and the effect of the Ala12 mutation on PCOS symptoms has been closely studied, although some specific conclusions are difficult to reach. There are conflicting reports regarding the effect of this allele on BMI: either linked with increased BMI [45, 52-55], lower BMI [41, 56-59], or not associated at all [45, 60-64]. Current assumptions are that differential environmentalinteractions between populations can modify the function of this polymorphism. However, the relationship between Pro12Ala and insulin sensitivity appears more conclusive. Populations of women positive for Ala12 and PCOS have lower fasting insulin, reduced measures of systemic insulin resistance, lower insulin secretion, and lower hirsutism scores than women without the allele $[54,65,66]$. Consequently, the frequency of this allele is much lower in groups categorised as PCOS $[54,65,67]$. It appears that the Pro12Ala polymorphism of the PPARG gene may be a modifier of insulin resistance in women with PCOS, which can have a profound influence on fertility (see Section 4.1).

Another PPARG2-specific polymorphism is the rare Pro115Gln substitution in exon 3 that results in permanent, ligand independent activation [44]. This induces excessive adipocyte differentiation, and as a result the 4 individuals known to carry this (nonfamilial) SNP suffer extreme obesity [44], although present with only moderate metabolic complications including Type 2 Diabetes. The reproductive implications of hyperactive PPARG2 have not been addressed in these subjects.

All other reported polymorphisms are located in regions common to both PPARG1 and PPARG2. The His447His polymorphisms resulting from a $\mathrm{C}$ to $\mathrm{T}$ substitution at nucleotide 1431 in exon 6 is a silent polymorphism that encodes histidine with either allele [55]. Also referred to as the C161T polymorphism, it is proposed that this substitution may modulate expression of PPARG by altering mRNA processing or translation, leading to increased adipocyte differentiation. Subsequently, carriers of the T allele have elevated BMI. The $\mathrm{T}$ allele is also more common in women with PCOS compared to non-PCOS BMI-matched controls [45], and therefore has suspected involvement in the high incidence of obesity in PCOS population. However, both PCOS subjects and controls with $\mathrm{T}$ allele appear to be protected from other complicating symptoms of obesity, having better insulin sensitivity in addition to lower circulating testosterone.

The remaining polymorphisms are all extremely rare and restricted to single families.

Reported by Barroso et al. [46] and Savage et al. [47], there is a PPARG1 Pro467Leu substitution in the region required for ligand-dependent transactivation (PPARG2 residue 495) which results in impaired coactivator recruitment and downstream transactivation. This mutation also inhibits basal gene activity and has been found within 4 members of a single family spanning 3 generations. Medical histories reveal that in addition to lipodystrophy and hypertension (both frequently associated with PPARG mutations), the female carrier also experienced oligomenorrhea and hirsutism, and required ART intervention to conceive. This, and a subsequent spontaneously conceived pregnancy were both complicated with severe pre-eclampsia. Treatment of the male carrier with rosiglitazone ( $8 \mathrm{mg} /$ day) was found to normalise chronic hyperglycaemia after 6 months, suggesting that the mutant PPARG protein is still able to be activated by exogenously sourced ligands, indicating the phenotypic profile of these subjects results from abnormal basal and endogenously activated PPARG activity.

Also identified by this study was a similarly positioned PPARG1 Val290Met mutation (PPARG2 residue 318) in a single female individual. This mutation results in a profound loss of PPARG function evidenced by both in vitro reporter gene activity, and in vivo response to rosiglitazone. Experiencing comparable metabolic complications to subjects with the Pro467Leu substitution, this individual also reported primary amenorrhoea, hirsutism, and acanthosis nigricans. Implications of these gynaecological and endocrine aberrations relating to conception and pregnancy have not been reported.

Another loss-of-function mutation is the phenylalanine to leucine substitution at position 388 (reported with respect to PPARG2, the substitution corresponds to residue 360 in PPARG1) found in 4 individuals from 3 generation of a single family [48]. Despite the reduction in normal PPARG function, concurrent treatment of one individual with both metformin and rosiglitazone ( $8 \mathrm{mg}$ daily) provided effective glycemic control. Two of the affected individuals were female (46-year-old mother and her 22-year-old daughter), with the older individual experiencing a history of irregular menses and polycystic ovarian disease, eventually treated with bilateral salpingo-oophorectomy. At the time of study, the daughter did not have any significant medical problems (other than diet-controlled hyperinsulinemia and mild type IV hyperlipoproteinia), with regular menses and no polycystic ovarian pathology observed.

A heterozygous arginine to cysteine mutation at position 397 in PPARG1 (corresponding to residue 425 in PPARG2) was identified in a 64-year-old woman in 2002 by Argarwal and Garg [49]. Although the effect on PPARG functionality 
has not been explicitly described, but the mutation lies in a region of the protein that forms a salt-bridge, and as a result, the mutated form may lack proper protein configuration. The Arg397Cys substitution was associated with lipodystrophy, elevated triglycerides, and early-onset Type 2 Diabetes. In addition, although pregnancy was never sought, moderate hirsutism as well as a history of delayed menarche (age 18) and subsequently irregular menstrual cycles were reported.

Overall, these studies demonstrate that PPARG precisely controls various aspect of systemic metabolism in humans. As female fertility is also disrupted in a significant number of these patients, it is likely that PPARG regulates female reproduction either directly, by intrinsic actions within reproductive organs such as the ovary, or indirectly via the myriad effects on metabolic tissues such as adipose and liver. To better define links between the metabolic and reproductive consequences observed in so many of these PPARG mutations, it would be interesting to recapitulate, in a tissuespecific manner, some of these PPARG genetic aberrations in mice.

\section{LIGANDS}

Together with expression of PPARG itself, availability of ligands is a primary regulating factor determining the ability of PPARG to influence target gene expression. Ligands can be produced endogenously, providing physiological significance, or sourced exogenously, as therapeutic factors given to target specific metabolic and reproductive symptoms.

\subsection{Endogenous ligands: physiological function of PPARG}

All PPARs bind and are activated by naturally occurring fatty acids and their metabolites [68], thus acting as fatty acid-activated receptors that function as key regulators of glucose and cholesterol metabolism. The precise nature of endogenous PPARG ligand binding and activation remains poorly defined and more research is needed in this area. However, the potential for important physiological ovarian PPARG activation is considerable, as many natural ligands have been shown to be present within the ovary, and produced locally by ovarian cells. Included in this list are $\omega 3$ - and $\omega 6$-polyunsaturated fatty acids (PUFAs) such as the essential fatty acids linoleic acid, linolenic acid, arachidonic acid, and eicosapentanoic acid ([69] and reviewed [34]). Additional PPARG agonists such as prostaglandin metabolites of these substances and immunologically-derived eicosanoids are also produced within the ovarian environment in a hormonally regulated manner, with elevated production as ovulation progresses [70-73]. It is possible that PPARG may have a role in the feed-forward production of eicosanoid ligands, based on identification of a PPRE in the prostaglandin-endoperoxide synthase 2 (a.k.a. COX-2) promoter [74], which would facilitate amplified production of pro-ovulatory prostaglandins.

\subsection{Exogenous ligands: therapeutic application of PPARG activation}

As information emerges regarding the endogenous roles for naturally activated PPARG within the ovarian follicular environment, other evidence of PPARG involvement with ovarian function comes from reports utilising synthetic PPARG ligands, specifically, administration of TZDs to women diagnosed with PCOS (Table 2).

PCOS is the leading cause of infertility and menstrual irregularities in women of reproductive age and is characterised by chronic hyperandrogenic anovulation [90]. This is thought to be due, in general, to hypothalamic-pituitary axis dysregulation causing elevated basal LH levels that overstimulate cells of the theca interna [91]. Insulin resistance also appears to contribute to the syndrome in many instances [92], as the pituitary responds to elevated plasma levels of insulin to augment $\mathrm{LH}$ release [91].

The potential merits of applying TZDs to improve reproductive outcomes in infertile PCOS women was first demonstrated by Azziz et al. [93]. Since then, treatment of PCOS patients with the TZDs rosiglitazone or pioglitazone have been shown to not only improve insulin action in peripheral tissues, attenuate hyperinsulinemia, and lower circulating levels of lipids $[92,94]$, but also to improve a range of reproductive outcomes particularly circulating sex hormone levels, and ovulation rate [77, 88, 90, 95-97] (see recent reports summarised in Table 2).

The beneficial effects of TZDs on ovarian PCOS symptoms were first attributed to improvements in defective insulin action and secretion [92]. However, actions upon various ovarian cells directly illustrated both in vitro $[1,9,14$, $98,99]$ and in vivo $[100,101]$ confirms a direct interaction between these compounds and ovarian PPARG.

Particular focus has been directed upon the effect of PPARG activation on the synthesis of ovarian steroid hormones and the expression of many rate-limiting steroidogenic enzymes has been investigated.

(1) Steroidogenic acute regulatory protein (StAR): facilitates that rapid mobilization of cholesterol for initial catalysis to pregnenolone by the $\mathrm{P} 450$-side chain cleavage enzyme located within the mitochondria [102]. It has been recently reported that both rosiglitazone and pioglitazone significantly up regulate StAR protein synthesis by human granulosa cells in vitro [103].

(2) $3 \beta$-hydroxysteroid dehydrogenase ( $3 \beta$-HSD): catalyses the conversion of pregnenolone to progesterone by luteal cells [104]. Work on porcine granulosa cells has found that troglitazone competitively inhibits $3 \beta$-HSD enzyme activity within these cells [99].

(3) Steroid 17-alpha-hydroxylase (P450c17): converts progesterone to androgen within ovarian theca cells [105]. Conflicting reports have arisen regarding the effect of TZDs on the expression and activity of this enzyme, many of which may be artefacts of various culture conditions. P450c17 mRNA production has been found to increase following porcine thecal cell exposure to TZDs [8], whilst other reports indicate suppression 
TABLE 2: Summary of reports published within the past 2 years on the use of PPARG activating agents for reproductive symptoms. Abbreviations used: AUC, area under the curve; BMI body mass index; CC clomiphene citrate; DHEA-S dehydroepiandrosterone sulfate; E2, estradiol; FAI, free androgen index; FSH, follicle-stimulating hormone; GnRH, gonadotropin releasing hormone; HbA(1C), haemoglobin A1C; HDL-C, high density lipoprotein-cholesterol; HOMA, homeostasis model of assessment for insulin sensitivity; IGF1 insulin-like growth factor 1; IGFBP-1/3, insulin-like growth factor binding protein 1 or 3; LDL-C, low density lipoprotein-cholesterol; LH, luteinizing hormone; OGTT, oral glucose tolerance test; PCOS, polycystic ovary syndrome; QUICKI, quantitative insulin-sensitivity check index; SHBG, sex hormone binding globulin; T, testosterone; WHR, waist to hip ratio.

\begin{tabular}{|c|c|}
\hline Reference: & Rautio et al. [75] and Rautio et al. [76] \\
\hline Patient profile: & Overweight but not obese PCOS $(n=30)$ \\
\hline PPAR agonist: & Rosiglitazone ( $4 \mathrm{mg}$ once daily for 2 weeks then $4 \mathrm{mg}$ twice daily for 16 weeks) \\
\hline Metabolic outcomes: & $\begin{array}{l}\text { Serum C-reactive protein levels, leukocyte count, and alanine aminotransferase enzyme activity } \\
\text { decreased, but lipid and blood pressure did not change. Glucose tolerance and peripheral insulin } \\
\text { response normalized in the rosiglitazone group. }\end{array}$ \\
\hline Reproductive outcomes: & $\begin{array}{l}\text { Rosiglitazone improved menstrual cyclicity, SHBG levels; and decreased serum levels of } \\
\text { androstenedione, 17-hydroxyprogesterone (17-OHP), DHEA and DHEA-S. }\end{array}$ \\
\hline Reference: & Rouzi and Ardawi [77] \\
\hline Patient profile: & Obese PCOS $(n=12)$ \\
\hline PPAR agonist: & $\begin{array}{l}\text { Rosiglitazone ( } 4 \mathrm{mg} \text { twice daily for } 3 \text { cycles, CC administered for } 5 \text { days starting } 3 \text { days after } \\
\text { rosiglitazone initiated) }\end{array}$ \\
\hline Metabolic outcomes: & $\begin{array}{l}\text { No changes in fasting plasma glucose or } \mathrm{HbA}(1 \mathrm{C}) \text { or IGFBP- } 3 \text { values. Fasting serum insulin, } \\
\text { DHEA-S, androstenedione, and IGF-1 levels decreased significantly and IGFBP-1 exhibited } \\
\text { significant increases. }\end{array}$ \\
\hline Reproductive outcomes: & $\begin{array}{l}\text { Total-T, free-T, LH, and SHBG decreased. Follicular development and ovulation rate increased, } \\
\text { trend for increased pregnancy rate in group receiving short-term administration of rosiglitazone } \\
\text { compared to matched control receiving metformin. }\end{array}$ \\
\hline Reference: & Mitkov et al. $[78]$ \\
\hline Patient profile: & Obese, insulin resistant PCOS $(n=15)$ \\
\hline PPAR agonist: & Rosiglitazone (4 mg/day for 12 weeks) \\
\hline Metabolic outcomes: & Hyperinsulinemia and insulin resistance normalized. \\
\hline Reproductive outcomes: & $\begin{array}{l}\text { Total-T and FAI profile tended to normalise. Number of women with oligomenorrhea was } \\
\text { reduced by } 67 \%\end{array}$ \\
\hline Reference: & Cataldo et al. [79] \\
\hline Patient profile: & Insulin resistant PCOS ( $n=11-16 /$ group $)$ \\
\hline PPAR agonist: & Rosiglitazone (2, 4 or 8 mg/day for 12 weeks) \\
\hline Metabolic outcomes: & Steady state plasma glucose declined and hyperinsulinemia fell in a dose-dependent manner. \\
\hline Reproductive outcomes: & $\begin{array}{l}\text { Serum LH, total-T, and free-T were unchanged; SHBG increased. Ovulation occurred in } 55 \% \text {, } \\
\text { without significant dose dependence. Before and during treatment, ovulators on rosiglitazone } \\
\text { had lower circulating insulin and free-T and higher SHBG than nonovulators. }\end{array}$ \\
\hline Reference: & Lemay et al. $[80]$ \\
\hline Patient profile: & Overweight, insulin resistant PCOS $(n=15)$ \\
\hline PPAR agonist: & Rosiglitazone (4 mg/day for 6 months) \\
\hline Metabolic outcomes: & $\begin{array}{l}\text { Plasma insulin, insulin resistance indices and insulin AUC in response to OGTT all decreased } \\
\text { compared to controls receiving antiandrogenic estrogen-progestin. Effect on lipids was limited. }\end{array}$ \\
\hline Reproductive outcomes: & No significant effect on androgens or hirsutism. \\
\hline Reference: & Garmes et al. [81] \\
\hline Patient profile: & Obese insulin resistant PCOS $(n=15)$ \\
\hline PPAR agonist: & Pioglitazone (30 mg/day for 8 weeks) \\
\hline Metabolic outcomes: & Insulin response to OGTT significantly decreased. \\
\hline Reproductive outcomes: & $\begin{array}{l}\text { Total-T and free-T levels decreased, SHBG increased, and LH response to GnRH stimulation } \\
\text { decreased. }\end{array}$ \\
\hline Reference: & Yilmaz et al. $[82-84]$ \\
\hline Patient profile: & Obese or lean PCOS ( $n=20$ obese, $n=20$ lean) \\
\hline PPAR agonist: & Rosiglitazone ( $4 \mathrm{mg} /$ day for 12 weeks) \\
\hline Metabolic outcomes: & $\begin{array}{l}\text { Indices of oxidative stress improved. HOMA, insulin AUC, fasting insulin and C-peptide levels } \\
\text { decreased significantly. Glucose/insulin ratio and BMI increased }\end{array}$ \\
\hline
\end{tabular}


TABle 2: Continued.

\begin{tabular}{|c|c|}
\hline Reference: & Rautio et al. [75] and Rautio et al. [76] \\
\hline Patient profile: & Overweight but not obese PCOS $(n=30)$ \\
\hline PPAR agonist: & Rosiglitazone ( $4 \mathrm{mg}$ once daily for 2 weeks then $4 \mathrm{mg}$ twice daily for 16 weeks) \\
\hline Metabolic outcomes: & $\begin{array}{l}\text { Serum C-reactive protein levels, leukocyte count, and alanine aminotransferase enzyme activity } \\
\text { decreased, but lipid and blood pressure did not change. Glucose tolerance and peripheral insulin } \\
\text { response normalized in the rosiglitazone group. }\end{array}$ \\
\hline Reproductive outcomes: & $\begin{array}{l}\text { Rosiglitazone improved menstrual cyclicity, SHBG levels; and decreased serum levels of } \\
\text { androstenedione, 17-hydroxyprogesterone (17-OHP), DHEA and DHEA-S. }\end{array}$ \\
\hline Reproductive outcomes: & $\begin{array}{l}\text { Seurm levels of free-T, androstenedione, and DHEA-S decreased significantly. Menstrual } \\
\text { disturbances improved in } 61.5 \% \text { of lean and } 53.8 \% \text { of obese patients. In a second cohort of } \\
\text { patients, menstrual cycles became regular in } 87.8 \% \text {. }\end{array}$ \\
\hline Reference: & Tarkun et al. [85] \\
\hline Patient profile: & Young, lean PCOS $(n=31)$ \\
\hline PPAR agonist: & Rosiglitazone (4 mg/day for 12 months) \\
\hline Metabolic outcomes: & $\begin{array}{l}\text { Fasting insulin and insulin resistance indices significantly improved. No changes in BMI, waist } \\
\text { circumference, serum total cholesterol, or LDL-C. Serum C-reactive protein levels decreased; and } \\
\text { endothelium-dependent vascular responses improved. }\end{array}$ \\
\hline Reproductive outcomes: & $\begin{array}{l}\text { Significant decreases in serum T, although no change in FSH and LH levels. Hirsutism score } \\
\text { decreased significantly after treatment. } 77.4 \% \text { of women reverted to regular menstrual cycles. } \\
\text { Levels of SHBG increased significantly after treatment. }\end{array}$ \\
\hline Reference: & Dereli et al. [86] \\
\hline Patient profile: & Nonobese PCOS ( $n=20 /$ group) \\
\hline PPAR agonist: & Rosiglitazone ( $2 \mathrm{mg} /$ day or $4 \mathrm{mg} /$ day for 8 months) \\
\hline Metabolic outcomes: & $\begin{array}{l}75 \% \text { of women in the } 2 \mathrm{mg} \text { group and } 95 \% \text { in the } 4 \mathrm{mg} \text { group achieved normal glucose tolerance. } \\
\text { Improved insulin resistance in a dose-related fashion, without adverse events or liver enzyme } \\
\text { elevations. }\end{array}$ \\
\hline Reproductive outcomes: & $\begin{array}{l}\text { Decreased free- } \mathrm{T} \text { levels were better in the } 4 \mathrm{mg} \text { group than the } 2 \mathrm{mg} \text { group, and } 70 \% \text { of } \\
\text { women in the } 2 \mathrm{mg} \text { group and } 85 \% \text { of women in the } 4 \mathrm{mg} \text { group achieved ovulatory } \\
\text { menses. }\end{array}$ \\
\hline Reference: & Mehta et al. [87] \\
\hline Patient profile: & Obese PCOS $(n=9)$ \\
\hline PPAR agonist: & Pioglitazone ( $45 \mathrm{mg} /$ day for 20 weeks) \\
\hline Metabolic outcomes: & Significant improvement in insulin sensitivity \\
\hline Reproductive outcomes: & $\begin{array}{l}\text { LH levels, LH pulse frequency and amplitude, as well as gonadotropin responses to GnRH were } \\
\text { not influenced. }\end{array}$ \\
\hline Reference: & Ortega-González et al. [88] \\
\hline Patient profile: & Obese, insulin resistant PCOS $(n=25)$ \\
\hline PPAR agonist: & Pioglitazone (30 mg/day for 6 months) \\
\hline Metabolic outcomes: & $\begin{array}{l}\text { Body weight, BMI, and WHR increased significantly. Fasting insulin and insulin AUC during a } \\
\text { 2-h OGTT decreased. Insulin resistance decreased and insulin sensitivity increased after } \\
\text { treatment with either pioglitazone or metformin received by control group. }\end{array}$ \\
\hline Reproductive outcomes: & $\begin{array}{l}\text { Hirsutism, free-T and androstenedione declined to a similar extent after treatment } \\
\text { with either drug. Treatment with both drugs was associated with the occurrence of } \\
\text { pregnancy }\end{array}$ \\
\hline Reference: & Sepilian and Nagamani [89] \\
\hline Patient profile: & Obese insulin resistant PCOS $(n=12)$ \\
\hline PPAR agonist: & Rosiglitazone (4 mg/day for 6 months) \\
\hline Metabolic outcomes: & $\begin{array}{l}\text { Fasting insulin, insulin AUC, fasting glucose, and glucose AUC significantly decreased. No } \\
\text { significant change in BMI }\end{array}$ \\
\hline Reproductive outcomes: & $\begin{array}{l}\text { Both total-T, free-T and DHEA-S levels decreased significantly. No significant change in LH } \\
\text { levels. Levels of SHBG increased significantly after treatment, } 91.7 \% \text { of women reverted to regular } \\
\text { ovulatory cycles during the treatment period }\end{array}$ \\
\hline
\end{tabular}


of enzymatic expression and/or activity in primary porcine thecal cells or human cell lines [106-108].

(4) P450 aromatase (P450arom): aromatises androgen precursor to estradiol, and is expressed by ovarian granulosa [109] and luteal [110] cells. Although there is no correlation between the expression of the P450arom enzyme and PPARG itself during folliculogenesis, many reports have described the downregulation of P450arom following TZD exposure in human ovarian cell cultures [13, 111-113].

Taken together, these findings provide strong evidence for the direct effect of TZD administration and PPARG activation on ovarian hormonal synthesis and secretion. Specifically the following.

(1) Androgen: TZDs found to inhibit LH- and insulinstimulated androgen biosynthesis by purified porcine thecal [108], and mixed human ovarian [98] cells. They have also been found to reduce plasma testosterone levels in women with PCOS $[76,77,81-84,86$, $89,91,97,114,115]$.

(2) Estrogen: While it is accepted that TZDs indeed influence estrogen secretion, estrogenic responses to TZDs appear to be dependent on confounding factors such as species, age, and endocrine setting. For instance, TZDs have been found to increase estradiol secretion [2], and decrease estradiol production [116]. PPARG activation by TZDs and phthalate toxins are believed to mediate the antiestrogenic effects of these agents in cultured rat granulosa cells [116], and TZDs have also been found to suppress stimulated estradiol secretion in human granulosa cell cultures [98].

(3) Progesterone: As for estrogen, progesterone responses to PPARG activation via natural or endogenous ligands are unclear, and are probably regulated by species, and stage of folliculogenesis. Most publications investigating a range of species, including primary bovine, ovine, porcine, or rodent cell cultures, report increases in progesterone secretion following administration of PPARG activators in vitro [2, 8-10], whilst some others suggest inhibition of stimulated progesterone secretion by porcine granulosa cells [14].

The net influence of TZD treatment on ovarian PPARG activation and subsequent steroidogenesis in vivo remains poorly defined across all species investigated. The most conclusive evidence for an advantageous outcome on hormonal (specifically androgen) profile following treatment is observed in women with PCOS, as overviewed in Table 2. As a result, increasing attention may be paid towards the application of these drugs in such conditions of significant hormonal perturbations.

Rosiglitazone and pioglitazone are currently listed as a Pregnancy Category C drug (i.e., not tested for use during human pregnancy), and some side effects of TZD administration, such as weight gain, fluid retention (reviewed in [117]), and possible bone demineralisation [118], preclude their widespread use during pregnancy. However, in vitro treatment of 2 cell mouse embryos, or in vivo treatment of pregnant mice with rosiglitazone was not found to impact upon normal blastocyst development, or litter rates and sizes [119]. In situations where conception has occurred following TZD treatment for PCOS, no adverse fetal outcomes have been observed $[88,96,120]$. Also in a recent study, examining tissue obtained from women with scheduled pregnancy terminations, it was found that placental transfer of maternally administered rosiglitazone to fetal tissues is minimal in the first 10 weeks of pregnancy [121].

\section{MECHANISMS: PPARG REGULATION OF METABOLIC AND IMMUNE FACTORS INFLUENCING FEMALE FERTILITY}

PPARG is known to regulate many pathways involving insulin sensitivity, glucose metabolism, adipokine signalling, lipid uptake and metabolism, and secretion of inflammatory mediators. As a result, PPARG is being revealed as a key mediator of the fundamental metabolic and immune contributions that are required for normal female fertility.

\subsection{Insulin sensitivity}

Normal insulin sensitivity and subsequently efficient metabolism of glucose are essential for healthy reproduction in the female. Conditions of hyperinsulinemia can interfere with normal ovarian cell function or be indirectly associated with other hormonal conditions detrimental to optimal fertility [122-124]. Also, exposure to high levels of glucose can have a deleterious effect on the oocyte $[125,126]$. By normalising peripheral insulin signalling, PPARG activation can circumvent many of these adverse effects of hyperinsulinemia, as well as those detrimental outcome associated with persistently elevated blood glucose levels.

The genetic studies detailed above, and the pharmacokinetics of TZD treatment improving insulin sensitivity are both consistent with a direct role for PPARG in the regulation of cellular insulin utilization. Despite this, it remains to be determined exactly how TZD treatment and subsequent PPARG activation impacts gene expression directly related to insulin signalling and glucose uptake (through genes such as the insulin receptor (IR), IR-substrates, and glucose transporters), as a range of conflicting results have emerged. Suggested mechanisms include increases in glucosetransport protein 4 (GLUT4), stimulation of phosphatidyl-3-kinase andmodified phosphorylation of insulin receptor substrates [127-133]. In addition, it is well accepted that activation of PPARG does improve not only basal hepatic glucose secretion, but also peripheral insulin-stimulated glucose uptake, potentially indirectly via reduction of FFA, TNF $\alpha$, plasminogen activator inhibitor-1, and other autocrine/endocrine signalling molecules which otherwise interfere with efficient insulin signalling (reviewed in [134]). In this way, PPARG activation may improve female infertility exacerbated by obesity and insulin resistance [25, 135-141].

New reports are also describing some of the first investigations into the ovarian-specific responses to TZD that facilitate insulin sensitivity in this tissue. The work of Seto-Young et al. [103] has shown that ovarian cells directly respond to 
TZDs to increase transcription of insulin signalling components including IR alpha and beta subunits and IRS-1, which would subsequently provide more efficient signal transduction and cellular response to insulin.

\subsection{Adipokines: leptin and adiponectin}

Produced primarily by adipose tissue, leptin and adiponectin are "adipokines" with contrasting actions on insulin sensitivity. Whilst other adipokines such as visfatin and retinolbinding protein 4 (RBP-4) are also linked with insulin sensitivity [142, 143] and the incidence of PCOS [144, 145], leptin and adiponectin are of particular interest to those investigating female reproduction as it is known their presence can be detected by ovarian cells which express leptin and adiponectin receptors. In addition, although only the adiponectin promoter has been shown to contain a PPRE [146], transcriptional activity of both leptin and adiponectin genes is known to be decreased and increased, respectively, in the presence of PPARG-activating ligands [147-151]. In this way, they can operate as secondary messengers of signals initiated by PPARG activation.

Leptin receptors are present in the granulosa and thecal layers of the ovary $[152,153]$, and have been shown to be cyclically regulated [154]. Leptin appears to influence ovarian gonadotropin and steroid secretion [152, 153, 155], and affect oocyte quality and developmental potential [156, 157].

Adiponectin receptors AdipoR1 and AdipoR2 are also both expressed by ovarian tissue [158] and adiponectin itself has been identified within the follicular fluid of developed follicles in similar concentrations to that observed in the serum [159]. Adiponectin appears to be involved in many processes including those essential for ovulation, such as induction of COX-2 and prostaglandin E synthase expression in ovarian granulosa cells [159].

As the entire range of leptin and adiponectin effects on ovarian cellular functions, including the outcomes of PPARG activation (including enhancement of insulin sensitivity), are gradually established, it is likely we will find that the improvements to reproductive profiles and ovarian function of sub-fertile or infertile women treated with TZDs are mediated, at least in part, through modulation of these two adipokines.

\subsection{Lipid uptake: CD36 and SCARB1}

PPARG has a critical role in the regulation of adipocyte differentiation [94]. Among the best characterised PPARG target genes are those involved in lipid metabolism, including phosphoenolpyruvate carboxykinase [160], lipoprotein lipase [161], fatty acid binding protein $[162,163]$, and CD36 and SCARB1 [164, 165]. CD36 and SCARB1, class B scavenger receptors that mediate the endocytosis or selective cholesterol uptake from oxLDL and HDL lipoproteins, are also both strongly expressed by the ovary. The CD36 antigenis highly expressed by granulosa cells of preantral and earlyantral follicles, with moderatestaining also evident in the vascular thecal layers [166].In this context, CD36 has been reported as a facilitator of thrombospondins- 1 and -2 activities [166, 167], influencing cell adhesion, wound healing, and angiogenesis [168, 169]; important components of the tissue and cellular changes that occur during the ovarian cycle. CD36 is upregulated following activation of PPARG in macrophages $[164,170]$, and a summary of PPARG control of gene expression [171] suggested this might act as a positive feedback mechanism, such that more potential PPARG ligands can be imported, enhancing expression of both PPARG and CD36.

Ovarian SCARB1 expression appears to be strongly associated with HDL-cholesterol ester requirement for production of androgen for aromatase-mediated conversion to estradiol by the granulosa cells, and progesterone synthesis by luteal cells. Thecal cells consistently express high levels of SCARB1 at all stages of both healthy and atretic follicle development [172], and high expression is also found within luteal structures [173].

In these respects, PPARG activation may have profound influence on ovarian function through the regulation of these genes or others regulating lipid metabolism, by affecting availability of substrate for hormone synthesis, and the remodelling of tissue structures required for oocyte release, luteinization, and luteolysis.

\subsection{Suppression of chronic inflammation}

An important role for PPARG is the suppression of immune cell synthesis and secretion of proinflammatory mediators [174-182] (reviewed [183-185]). The role of the immune system in female fertility is critical, both systemically, and locally at the ovarian level.

In addition, there are also interesting correlations between the development of adiposity, insulin resistance and, chronic inflammation. Increased serum concentrations of TNF, NO, and IL-6 are strongly associated with obesity [186, 187], and proinflammatory cytokines sourced from adipose tissue including TNF, and IL-6 are among several important factors that participate in the development of insulin resistance and type 2 diabetes mellitus [188-191]. Interestingly, together with central adiposity and insulin resistance, we also find aspects of systemic inflammation independently associated with impaired female fertility and PCOS [192, 193]. PPARG is implicated in improvements to the systemic inflammation observed in obese and insulin resistant individuals treated with TZDs. These studies describe reductions in serum C-reactive protein, IL-6, and soluble TNF receptor 2 [194-198]. Other studies investigating the chronically inflamed profile of PCOS patients support these findings, reporting that in addition to restoring menstrual cyclicity and improving markers of hyperandrogensism, TZD treatment is able to lower circulating C-reactive protein levels and the number of circulating leukocytes $[75,85]$.

\subsection{Ovarian macrophages}

Macrophages, dendritic cells, lymphocytes, and neutrophils have unique roles in the context of ovarian physiology, and are essential for the normal regulation of ovulation and control of the reproductive cycle [5, 199-201]. Macrophage 
distribution and numbers within the ovary varies across the cycle, influenced by gonadotrophins and ovarian steroidogenic hormones. Resident macrophages are present in the theca and stroma of the ovary during the late stages of folliculogenesis [202]. Once the LH surge commences prior to ovulation, there is a massive recruitment of new leukocytes from the circulation into the theca of the preovulatory follicle $[202,203]$, where they function to release proinflammatory cytokines and mediators assisting the breakdown of the ovarian epithelium at ovulation. Their presence persists until after ovulation, further increasing in number in the developing and regressing corpus luteum [204].

Ovarian macrophages maintain high levels of PPARG transcript expression until a significant reduction in response to the proovulatory LH surge [1]. Immediately following ovulation, expression is restored to high preovulatory levels [1]. In vitro treatment of purified ovarian macrophages with the TZD troglitazone has been shown to significantly alter proinflammatory gene expression [1]. Specifically, these cells respond to TZD exposure by significantly suppressing mRNA production of NOS2 (or inducible Nitric Oxide Synthase, iNOS), the enzyme that catalyses the reaction producing the potent vasodilator, nitric oxide (NO). In the human, NO seems to direct follicular selection and maturation [205], and application of this NO property to IVF patients, deemed "poor responders", has been found to increase the number of oocytes retrieved [206]. This is an indication that recruited and specialized ovarian macrophages can potentially respond directly to TZDs administered systemically, and can regulate the availability of ovulatory mediators. Such responses parallel the anti-inflammatory effects of PPARG activation in nonovarian-activated macrophages [171], but was here found to be specific to macrophages closely associated with the ovarian environment (distinct to those located in the peritoneal cavity for instance). This illustrates the unique influence of the ovarian milieu on normal PPARG function and effects.

\section{CONCLUSIONS}

Many diverse endocrine and metabolic components profoundly influence female fertility, including hormone production as well as the development and ovulation of healthy oocytes. The role of PPARG in these events is two-fold. PPARG activation of transcription has outcomes operating both directly within the ovarian structure itself, and also indirectly through influences on other tissue systems such as the adipose tissue and immune cells (Figure 3). In this way, PPARG controls key signals regulating the capacity for normal reproduction. As PPARG is able, and required, to regulate many of these actions, it is important that the roles of PPARG be carefully considered as new concepts develop regarding the effects of dietary supplements such as PUFAs, which are PPARG ligands, and the consequences of increased immunological activation, such as occurs during obesity. As the health crisis surrounding the obesity epidemic widens to include the damaging effects on female fertility, it is important to remember the systemic implications of metabolism and immune regulation on female fertility, and

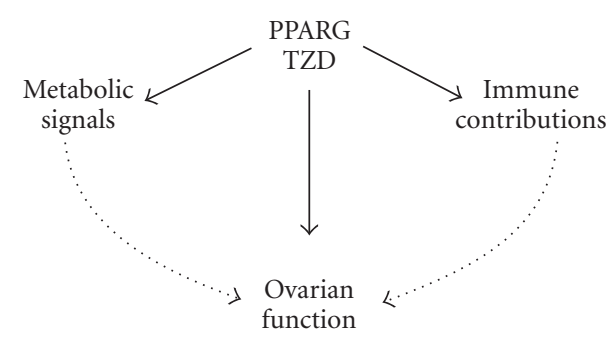

FIGURE 3: Schematic summarising the developing concept of PPARG influence on ovarian function and female fertility. PPARG is able to strongly influence the activity of ovarian cells directly, in particular steroidogenesis and tissue remodelling. In addition, PPARG can further influence ovarian function via regulation of external metabolic signals and immune cell contributions.

to consider the role of PPARG in coordinating these contributions. Tremendous opportunity exists for those interested in elucidating further the exciting interactions between PPARG and female fertility. Publication of the most extensive list to date of all genes containing potential PPREs in their promoter regions [207] will provide a valuable tool for such research, as many identified genes have known functions within the context of ovarian physiology and pathology, in addition to characterized roles in other tissues, including macrophages and adipose tissue.

\section{REFERENCES}

[1] C. E. Minge, N. K. Ryan, K. H. Van Der Hoek, R. L. Robker, and R. J. Norman, "Troglitazone regulates peroxisome proliferator-activated receptors and inducible nitric oxide synthase in murine ovarian macrophages," Biology of Reproduction, vol. 74, no. 1, pp. 153-160, 2006.

[2] C. M. Komar, O. Braissant, W. Wahli, and T. E. Curry Jr., "Expression and localization of PPARs in the rat ovary during follicular development and the periovulatory period," Endocrinology, vol. 142, no. 11, pp. 4831-4838, 2001.

[3] C. M. Komar, "Peroxisome proliferator-activated receptors (PPARs) and ovarian function-implications for regulating steroidogenesis, differentiation, and tissue remodeling," Reproductive Biology and Endocrinology, vol. 3, no. 41, 2005.

[4] P. Froment, F. Gizard, D. Defever, B. Staels, J. Dupont, and P. Monget, "Peroxisome proliferator-activated receptors in reproductive tissues: from gametogenesis to parturition," Journal of Endocrinology, vol. 189, no. 2, pp. 199-209, 2006.

[5] R. Wu, K. H. Van der Hoek, N. K. Ryan, R. J. Norman, and R. L. Robker, "Macrophage contributions to ovarian function," Human Reproduction Update, vol. 10, no. 2, pp. 119 $133,2004$.

[6] O. Braissant, F. Foufelle, C. Scotto, M. Dauça, and W. Wahli, "Differential expression of peroxisome proliferator-activated receptors (PPARs): tissue distribution of PPAR- $\alpha,-\beta$, and $-\gamma$ in the adult rat," Endocrinology, vol. 137, no. 1, pp. 354-366, 1996.

[7] Y. Cui, K. Miyoshi, E. Claudio, et al., "Loss of the peroxisome proliferation-activated receptor $\gamma(\operatorname{PPAR} \gamma)$ does not affect mammary development and propensity for tumor formation but leads to reduced fertility," Journal of Biological Chemistry, vol. 277, no. 20, pp. 17830-17835, 2002. 
[8] P. D. Schoppee, J. C. Garmey, and J. D. Veldhuis, "Putative activation of the peroxisome proliferator-activated receptor $\gamma$ impairs androgen and enhances progesterone biosynthesis in primary cultures of porcine theca cells," Biology of Reproduction, vol. 66, no. 1, pp. 190-198, 2002.

[9] P. Froment, S. Fabre, J. Dupont, et al., "Expression and functional role of peroxisome proliferator-activated receptor- $\gamma$ in ovarian folliculogenesis in the sheep," Biology of Reproduction, vol. 69, no. 5, pp. 1665-1674, 2003.

[10] B. Löhrke, T. Viergutz, S. K. Shahi, et al., "Detection and functional characterisation of the transcription factor peroxisome proliferator-activated receptor $\gamma$ in lutein cells," Journal of Endocrinology, vol. 159, no. 3, pp. 429-439, 1998.

[11] H. Sundvold, A. Brzozowska, and S. Lien, "Characterisation of bovine peroxisome proliferator-activated receptors $\gamma 1$ and $\gamma 2$ : genetic mapping and differential expression of the two isoforms," Biochemical and Biophysical Research Communications, vol. 239, no. 3, pp. 857-861, 1997.

[12] K. G. Lambe and J. D. Tugwood, "A human peroxisomeproliferator-activated receptor- $\gamma$ is activated by inducers of adipogenesis, including thiazalidinedione drugs," European Journal of Biochemistry, vol. 239, no. 1, pp. 1-7, 1996.

[13] Y.-M. Mu, T. Yanase, Y. Nishi, et al., "Insulin sensitizer, troglitazone, directly inhibits aromatase activity in human ovarian granulosa cells," Biochemical and Biophysical Research Communications, vol. 271, no. 3, pp. 710-713, 2000.

[14] S. Gasic, Y. Bodenburg, M. Nagamani, A. Green, and R. J. Urban, "Troglitazone inhibits progesterone production in porcine granulosa cells," Endocrinology, vol. 139, no. 12, pp. 4962-4966, 1998.

[15] C. M. Komar and T. E. Curry Jr., "Localization and expression of messenger RNAs for the peroxisome proliferatoractivated receptors in ovarian tissue from naturally cycling and pseudopregnant rats," Biology of Reproduction, vol. 66, no. 5, pp. 1531-1539, 2002.

[16] M. Mohan, J. R. Malayer, R. D. Geisert, and G. L. Morgan, "Expression patterns of retinoid X receptors, retinaldehyde dehydrogenase, and peroxisome proliferator activated receptor $\gamma$ in bovine preattachment embryos," Biology of Reproduction, vol. 66, no. 3, pp. 692-700, 2002.

[17] C. Dreyer and H. Ellinger-Ziegelbauer, "Retinoic acid receptors and nuclear orphan receptors in the development of Xenopus laevis," International Journal of Developmental Biology, vol. 40, no. 1, pp. 255-262, 1996.

[18] C. M. Komar and T. E. Curry Jr., "Inverse relationship between the expression of messenger ribonucleic acid for peroxisome proliferator-activated receptor $\gamma$ and P450 side chain cleavage in the rat ovary," Biology of Reproduction, vol. 69, no. 2, pp. 549-555, 2003.

[19] A. Chawla, E. J. Schwarz, D. D. Dimaculangan, and M. A. Lazar, "Peroxisome proliferator-activated receptor (PPAR) $\gamma$ : adipose-predominant expression and induction early in adipocyte differentiation," Endocrinology, vol. 135, no. 2, pp. 798-800, 1994.

[20] A. Chawla, Y. Barak, L. Nagy, D. Liao, P. Tontonoz, and R. M. Evans, "PPAR- $\gamma$ dependent and independent effects on macrophage-gene expression in lipid metabolism and inflammation," Nature Medicine, vol. 7, no. 1, pp. 48-52, 2001.

[21] P. Tontonoz, E. Hu, and B. M. Spiegelman, "Stimulation of adipogenesis in fibroblasts by PPAR $\gamma 2$, a lipid-activated transcription factor," Cell, vol. 79, no. 7, pp. 1147-1156, 1994.

[22] E. D. Rosen, P. Sarraf, A. E. Troy, et al., "PPAR $\gamma$ is required for the differentiation of adipose tissue in vivo and in vitro," Molecular Cell, vol. 4, no. 4, pp. 611-617, 1999.
[23] Y. Barak, M. C. Nelson, E. S. Ong, et al., "PPAR $\gamma$ is required for placental, cardiac, and adipose tissue development," Molecular Cell, vol. 4, no. 4, pp. 585-595, 1999.

[24] M. J. Davies, "Evidence for effects of weight on reproduction in women," Reproductive BioMedicine Online, vol. 12, no. 5, pp. 552-561, 2006.

[25] R. J. Norman and A. M. Clark, "Obesity and reproductive disorders: a review," Reproduction, Fertility and Development, vol. 10, no. 1, pp. 55-63, 1998.

[26] Y.-M. Mu, T. Yanase, Y. Nishi, et al., "Saturated FFAs, palmitic acid and stearic acid, induce apoptosis in human granulosa cells," Endocrinology, vol. 142, no. 8, pp. 3590-3597, 2001.

[27] R. Jorritsma, M. L. César, J. T. Hermans, C. L. J. J. Kruitwagen, P. L. A. M. Vos, and T. A. M. Kruip, "Effects of nonesterified fatty acids on bovine granulosa cells and developmental potential of oocytes in vitro," Animal Reproduction Science, vol. 81, no. 3-4, pp. 225-235, 2004.

[28] T. Vanholder, J. L. M. R. Leroy, A. Van Soom, et al., "Effect of non-esterified fatty acids on bovine granulosa cell steroidogenesis and proliferation in vitro," Animal Reproduction Science, vol. 87, no. 1-2, pp. 33-44, 2005.

[29] M. Mitchell, D. T. Armstrong, R. L. Robker, and R. J. Norman, "Adipokines: implications for female fertility and obesity," Reproduction, vol. 130, no. 5, pp. 583-597, 2005.

[30] A. M. Bodles, V. Varma, A. Yao-Borengasser, et al., "Pioglitazone induces apoptosis of macrophages in human adipose tissue," Journal of Lipid Research, vol. 47, no. 9, pp. 20802088, 2006.

[31] L. Fajas, J.-C. Fruchart, and J. Auwerx, "PPAR $\gamma 3$ mRNA: a distinct PPAR $\gamma$ mRNA subtype transcribed from an independent promoter," FEBS Letters, vol. 438, no. 1-2, pp. 55-60, 1998.

[32] P. Tontonoz, R. A. Graves, A. I. Budavari, et al., "Adipocytespecific transcription factor ARF6 is a heterodimeric complex of two nuclear hormone receptors, PPAR $\gamma$ and RXR $\alpha$," Nucleic Acids Research, vol. 22, no. 25, pp. 5628-5634, 1994.

[33] H. Sundvold and S. Lien, "Identification of a novel peroxisome proliferator-activated receptor (PPAR) $\gamma$ promoter in man and transactivation by the nuclear receptor ROR $\alpha 1$," Biochemical and Biophysical Research Communications, vol. 287, no. 2, pp. 383-390, 2001.

[34] B. Desvergne and W. Wahli, "Peroxisome proliferatoractivated receptors: nuclear control of metabolism," Endocrine Reviews, vol. 20, no. 5, pp. 649-688, 1999.

[35] R. Mukherjee, L. Jow, G. E. Croston, and J. R. Paterniti Jr., "Identification, characterization, and tissue distribution of human peroxisome proliferator-activated receptor (PPAR) isoforms PPAR $\gamma 2$ versus PPAR $\gamma 1$ and activation with retinoid X receptor agonists and antagonists," Journal of Biological Chemistry, vol. 272, no. 12, pp. 8071-8076, 1997.

[36] L. Fajas, D. Auboeuf, E. Raspé, et al., "The organization, promoter analysis, and expression of the human PPAR $\gamma$ gene," Journal of Biological Chemistry, vol. 272, no. 30, pp. 1877918789, 1997.

[37] Y.-S. Tsai and N. Maeda, "PPAR $\gamma$ : a critical determinant of body fat distribution in humans and mice," Trends in Cardiovascular Medicine, vol. 15, no. 3, pp. 81-85, 2005.

[38] M. Stumvoll and H. Häring, "The peroxisome proliferatoractivated receptor- $\gamma 2$ Pro12Ala polymorphism," Diabetes, vol. 51, no. 8, pp. 2341-2347, 2002.

[39] P. D. G. Miles, Y. Barak, W. He, R. M. Evans, and J. M. Olefsky, "Improved insulin-sensitivity in mice heterozygous for PPAR- $\gamma$ deficiency," Journal of Clinical Investigation, vol. 105, no. 3, pp. 287-292, 2000. 
[40] H. Koutnikova, T.-A. Cock, M. Watanabe, et al., "Compensation by the muscle limits the metabolic consequences of lipodystrophy in PPAR $y$ hypomorphic mice," Proceedings of the National Academy of Sciences of the United States of America, vol. 100, no. 24, pp. 14457-14462, 2003.

[41] S. S. Deeb, L. Fajas, M. Nemoto, et al., "A Pro12Ala substitution in PPAR $\gamma 2$ associated with decreased receptor activity, lower body mass index and improved insulin sensitivity," $\mathrm{Na}$ ture Genetics, vol. 20, no. 3, pp. 284-287, 1998.

[42] J. Masugi, Y. Tamori, H. Mori, T. Koike, and M. Kasuga, "Inhibitory effect of a proline-to-alanine substitution at codon 12 of peroxisome proliferator-activated receptor- $\gamma$ 2 on thiazolidinedione-induced adipogenesis," Biochemical and Biophysical Research Communications, vol. 268, no. 1, pp. 178-182, 2000.

[43] H. J. Antoine, M. Pall, B. C. Trader, Y.-D. I. Chen, R. Azziz, and M. O. Goodarzi, "Genetic variants in peroxisome proliferator-activated receptor $\gamma$ influence insulin resistance and testosterone levels in normal women, but not those with polycystic ovary syndrome," Fertility and Sterility, vol. 87, no. 4, pp. 862-869, 2007.

[44] M. Ristow, D. Müller-Wieland, A. Pfeiffer, W. Krone, and C. R. Kahn, "Obesity associated with a mutation in a genetic regulator of adipocyte differentiation," New England Journal of Medicine, vol. 339, no. 14, pp. 953-959, 1998.

[45] F. Orio Jr., G. Matarese, S. Di Biase, et al., "Exon 6 and 2 peroxisome proliferator-activated receptor- $\gamma$ polymorphisms in polycystic ovary syndrome," Journal of Clinical Endocrinology and Metabolism, vol. 88, no. 12, pp. 5887-5892, 2003.

[46] I. Barroso, M. Gurnell, V. E. F. Crowley, et al., "Dominant negative mutations in human PPAR $y$ associated with severe insulin resistance, diabetes mellitus and hypertension," $\mathrm{Na}$ ture, vol. 402, no. 6764, pp. 880-883, 1999.

[47] D. B. Savage, G. D. Tan, C. L. Acerini, et al., "Human metabolic syndrome resulting from dominant-negative mutations in the nuclear receptor peroxisome proliferatoractivated receptor- $\gamma$," Diabetes, vol. 52, no. 4, pp. 910-917, 2003.

[48] R. A. Hegele, H. Cao, C. Frankowski, S. T. Mathews, and T. Leff, "PPARG F388L, a transactivation-deficient mutant, in familial partial lipodystrophy," Diabetes, vol. 51, no. 12, pp. 3586-3590, 2002.

[49] A. K. Agarwal and A. Garg, "A novel heterozygous mutation in peroxisome proliferator-activated receptor- $\gamma$ gene in a patient with familial partial lipodystrophy," Journal of Clinical Endocrinology and Metabolism, vol. 87, no. 1, pp. 408-411, 2002.

[50] T. E. Akiyama, S. Sakai, G. Lambert, et al., "Conditional disruption of the peroxisome proliferator-activated receptor $\gamma$ gene in mice results in lowered expression of ABCA1, ABCG1, and apoE in macrophages and reduced cholesterol efflux," Molecular and Cellular Biology, vol. 22, no. 8, pp. 2607-2619, 2002.

[51] D. Altshuler, J. N. Hirschhorn, M. Klannemark, et al., "The common PPAR $\gamma$ Pro12Ala polymorphism is associated with decreased risk of type 2 diabetes," Nature Genetics, vol. 26, no. 1, pp. 76-80, 2000.

[52] M. M. Swarbrick, C. M. L. Chapman, B. M. McQuillan, J. Hung, P. L. Thompson, and J. P. Beilby, "A Pro12Ala polymorphism in the human peroxisome proliferator-activated receptor- $\gamma 2$ is associated with combined hyperlipidaemia in obesity," European Journal of Endocrinology, vol. 144, no. 3, pp. 277-282, 2001.
[53] B. A. Beamer, C.-J. Yen, R. E. Andersen, et al., "Association of the Pro12Ala variant in the peroxisome proliferator- activated receptor- $\gamma 2$ gene with obesity in two Caucasian populations," Diabetes, vol. 47, no. 11, pp. 1806-1808, 1998.

[54] E. C. Tok, A. Aktas, D. Ertunc, E. M. Erdal, and S. Dilek, "Evaluation of glucose metabolism and reproductive hormones in polycystic ovary syndrome on the basis of peroxisome proliferator-activated receptor (PPAR) $-\gamma 2$ Pro12Ala genotype," Human Reproduction, vol. 20, no. 6, pp. 15901595, 2005.

[55] A. Meirhaeghe, L. Fajas, N. Helbecque, et al., "A genetic polymorphism of the peroxisome proliferator-activated receptor $\gamma$ gene influences plasma leptin levels in obese humans," $\mathrm{Hu}$ man Molecular Genetics, vol. 7, no. 3, pp. 435-440, 1998.

[56] A. Doney, B. Fischer, D. Frew, et al., "Haplotype analysis of the PPAR $\gamma$ Pro12Ala and C1431T variants reveals opposing associations with body weight," BMC Genetics, vol. 3, no. 1, p. 21, 2002.

[57] J. Ek, G. Andersen, S. A. Urhammer, et al., "Studies of the Pro12Ala polymorphism of the peroxisome proliferatoractivated receptor- $\gamma 2$ (PPAR- $\gamma 2$ ) gene in relation to insulin sensitivity among glucose tolerant caucasians," Diabetologia, vol. 44, no. 9, pp. 1170-1176, 2001.

[58] C. Vigouroux, L. Fajas, E. Khallouf, et al., "Human peroxisome proliferator-activated receptor- $\gamma 2$ : genetic mapping, identification of a variant in the coding sequence, and exclusion as the gene responsible for lipoatrophic diabetes," Diabetes, vol. 47, no. 3, pp. 490-492, 1998.

[59] J. Pihlajamäki, R. Miettinen, R. Valve, et al., "The Pro12Ala substitution in the peroxisome proliferator activated receptor $\gamma 2$ is associated with an insulin-sensitive phenotype in families with familial combined hyperlipidemia and in nondiabetic elderly subjects with dyslipidemia," Atherosclerosis, vol. 151, no. 2, pp. 567-574, 2000.

[60] A. Hamann, H. Münzberg, P. Buttron, et al., "Missense variants in the human peroxisome proliferator-activated receptor- $\gamma 2$ gene in lean and obese subjects," European Journal of Endocrinology, vol. 141, no. 1, pp. 90-92, 1999.

[61] J. Ringel, S. Engeli, A. Distler, and A. M. Sharma, "Pro12Ala missense mutation of the peroxisome proliferator activated receptor $\gamma$ and diabetes mellitus," Biochemical and Biophysical Research Communications, vol. 254, no. 2, pp. 450-453, 1999.

[62] Y. Mori, H. Kim-Motoyama, T. Katakura, et al., "Effect of the Pro12Ala variant of the human peroxisome proliferatoractivated receptor $\gamma 2$ gene on adiposity, fat distribution, and insulin sensitivity in Japanese men," Biochemical and Biophysical Research Communications, vol. 251, no. 1, pp. 195198, 1998.

[63] M. Koch, K. Rett, E. Maerker, et al., "The PPAR $\gamma 2$ amino acid polymorphism Pro12Ala is prevalent in offspring of type II diabetic patients and is associated to increased insulin sensitivity in a subgroup of obese subjects," Diabetologia, vol. 42, no. 6, pp. 758-762, 1999.

[64] K. Hara, T. Okada, K. Tobe, et al., "The Pro12Ala polymorphism in PPAR $\gamma 2$ may confer resistance to type 2 diabetes," Biochemical and Biophysical Research Communications, vol. 271, no. 1, pp. 212-216, 2000.

[65] M. Yilmaz, M. Ali Ergün, A. Karakoç, E. Yurtçu, N. Çakir, and M. Arslan, "Pro12Ala polymorphism of the peroxisome proliferator-activated receptor- $\gamma$ gene in women with polycystic ovary syndrome," Gynecological Endocrinology, vol. 22, no. 6, pp. 336-342, 2006. 
[66] S. Hahn, A. Fingerhut, U. Khomtsiv, et al., "The peroxisome proliferator activated receptor $\gamma$ Pro12Ala polymorphism is associated with a lower hirsutism score and increased insulin sensitivity in women with polycystic ovary syndrome," Clinical Endocrinology, vol. 62, no. 5, pp. 573-579, 2005.

[67] S. Korhonen, S. Heinonen, M. Hiltunen, et al., "Polymorphism in the peroxisome proliferator-activated receptor- $\gamma$ gene in women with polycystic ovary syndrome," Human Reproduction, vol. 18, no. 3, pp. 540-543, 2003.

[68] H. E. Xu, M. H. Lambert, V. G. Montana, et al., "Structural determinants of ligand binding selectivity between the peroxisome proliferator-activated receptors," Proceedings of the National Academy of Sciences of the United States of America, vol. 98, no. 24, pp. 13919-13924, 2001.

[69] J. Berger and D. E. Moller, "The mechanisms of action of PPARs," Annual Review of Medicine, vol. 53, pp. 409-435, 2002.

[70] A. Tsafriri, "Ovulation as a tissue remodelling process: proteolysis and cumulus expansion," Advances in Experimental Medicine and Biology, vol. 377, pp. 121-140, 1995.

[71] B. Dennefors, L. Hamberger, and T. Hillensjo, "Aspects concerning the role of prostaglandins for ovarian function," Acta Obstetricia et Gynecologica Scandinavica, vol. 113, supplement, pp. 31-41, 1983.

[72] G. Evans, M. Dobias, G. J. King, and D. T. Armstrong, "Production of prostaglandins by porcine preovulatory follicular tissues and their roles in intrafollicular function," Biology of Reproduction, vol. 28, no. 2, pp. 322-328, 1983.

[73] D. T. Armstrong, "Prostaglandins and follicular functions," Journal of Reproduction and Fertility, vol. 62, no. 1, pp. 283291, 1981.

[74] A. V. Pontsler, A. St Hilaire, G. K. Marathe, G. A. Zimmerman, and T. M. McIntyre, "Cyclooxygenase-2 is induced in monocytes by peroxisome proliferator activated receptor $\gamma$ and oxidized alkyl phospholipids from oxidized low density lipoprotein," Journal of Biological Chemistry, vol. 277, no. 15, pp. 13029-13036, 2002.

[75] K. Rautio, J. S. Tapanainen, A. Ruokonen, and L. C. MorinPapunen, "Rosiglitazone treatment alleviates inflammation and improves liver function in overweight women with polycystic ovary syndrome: a randomized placebo-controlled study," Fertility and Sterility, vol. 87, no. 1, pp. 202-206, 2007.

[76] K. Rautio, J. S. Tapanainen, A. Ruokonen, and L. C. MorinPapunen, "Endocrine and metabolic effects of rosiglitazone in overweight women with PCOS: a randomized placebocontrolled study," Human Reproduction, vol. 21, no. 6, pp. 1400-1407, 2006.

[77] A. A. Rouzi and M. S. M. Ardawi, "A randomized controlled trial of the efficacy of rosiglitazone and clomiphene citrate versus metformin and clomiphene citrate in women with clomiphene citrate-resistant polycystic ovary syndrome," Fertility and Sterility, vol. 85, no. 2, pp. 428-435, 2006.

[78] M. Mitkov, B. Pehlivanov, and D. Terzieva, "Metformin versus rosiglitazone in the treatment of polycystic ovary syndrome," European Journal of Obstetrics Gynecology and Reproductive Biology, vol. 126, no. 1, pp. 93-98, 2006.

[79] N. A. Cataldo, F. Abbasi, T. L. McLaughlin, et al., "Metabolic and ovarian effects of rosiglitazone treatment for 12 weeks in insulin-resistant women with polycystic ovary syndrome," Human Reproduction, vol. 21, no. 1, pp. 109-120, 2006.

[80] A. Lemay, S. Dodin, L. Turcot, F. Déchêne, and J.-C. Forest, "Rosiglitazone and ethinyl estradiol/cyproterone acetate as single and combined treatment of overweight women with polycystic ovary syndrome and insulin resistance," Human Reproduction, vol. 21, no. 1, pp. 121-128, 2006.

[81] H. M. Garmes, M. A. Tambascia, and D. E. ZantutWittmann, "Endocrine-metabolic effects of the treatment with pioglitazone in obese patients with polycystic ovary syndrome," Gynecological Endocrinology, vol. 21, no. 6, pp. 317323, 2005.

[82] M. Yilmaz, A. Biri, A. Karakoç, et al., "The effects of rosiglitazone and metformin on insulin resistance and serum androgen levels in obese and lean patients with polycystic ovary syndrome," Journal of Endocrinological Investigation, vol. 28, no. 11, pp. 1003-1008, 2005.

[83] M. Yilmaz, N. Bukan, G. Ayvaz, et al., "The effects of rosiglitazone and metformin on oxidative stress and homocysteine levels in lean patients with polycystic ovary syndrome," $\mathrm{Hu}$ man Reproduction, vol. 20, no. 12, pp. 3333-3340, 2005.

[84] M. Yilmaz, A. Karakoç, F. B. Törüner, et al., "The effects of rosiglitazone and metformin on menstrual cyclicity and hirsutism in polycystic ovary syndrome," Gynecological Endocrinology, vol. 21, no. 3, pp. 154-160, 2005.

[85] I. Tarkun, B. Çetinarslan, E. Türemen, T. Şahin, Z. Cantürk, and B. Komsuoğlu, "Effect of rosiglitazone on insulin resistance, C-reactive protein and endothelial function in nonobese young women with polycystic ovary syndrome," European Journal of Endocrinology, vol. 153, no. 1, pp. 115-121, 2005.

[86] D. Dereli, T. Dereli, F. Bayraktar, A. G. Ozgen, and C. Yilmaz, "Endocrine and metabolic effects of rosiglitazone in non-obese women with polycystic ovary disease," Endocrine Journal, vol. 52, no. 3, pp. 299-308, 2005.

[87] R. V. Mehta, K. S. Patel, M. S. Coffler, et al., "Luteinizing hormone secretion is not influenced by insulin infusion in women with polycystic ovary syndrome despite improved insulin sensitivity during pioglitazone treatment," Journal of Clinical Endocrinology and Metabolism, vol. 90, no. 4, pp. 2136-2141, 2005.

[88] C. Ortega-González, S. Luna, L. Hernández, et al., "Responses of serum androgen and insulin resistance to metformin and pioglitazone in obese, insulin-resistant women with polycystic ovary syndrome," Journal of Clinical Endocrinology and Metabolism, vol. 90, no. 3, pp. 1360-1365, 2005.

[89] V. Sepilian and M. Nagamani, "Effects of rosiglitazone in obese women with polycystic ovary syndrome and severe insulin resistance," Journal of Clinical Endocrinology and Metabolism, vol. 90, no. 1, pp. 60-65, 2005.

[90] M. F. M. Mitwally, N. K. Kuscu, and T. M. Yalcinkaya, "High ovulatory rates with use of troglitazone in clomipheneresistant women with polycystic ovary syndrome," Human Reproduction, vol. 14, no. 11, pp. 2700-2703, 1999.

[91] I. Hasegawa, H. Murakawa, M. Suzuki, Y. Yamamoto, T. Kurabayashi, and K. Tanaka, "Effect of troglitazone on endocrine and ovulatory performance in women with insulin resistance-related polycystic ovary syndrome," Fertility and Sterility, vol. 71, no. 2, pp. 323-327, 1999.

[92] D. A. Ehrmann, D. J. Schneider, B. E. Sobel, et al., "Troglitazone improves defects in insulin action, insulin secretion, ovarian steroidogenesis, and fibrinolysis in women with polycystic ovary syndrome," Journal of Clinical Endocrinology and Metabolism, vol. 82, no. 7, pp. 2108-2116, 1997.

[93] R. Azziz, D. Ehrmann, R. S. Legro, et al., "Troglitazone improves ovulation and hirsutism in the polycystic ovary syndrome: a multicenter, double blind, placebo-controlled trial," 
Journal of Clinical Endocrinology and Metabolism, vol. 86, no. 4, pp. 1626-1632, 2001.

[94] F. Picard and J. Auwerx, "PPAR $\gamma$ and glucose homeostasis," Annual Review of Nutrition, vol. 22, pp. 167-197, 2002.

[95] N. Brettenthaler, C. De Geyter, P. R. Huber, and U. Keller, "Effect of the insulin sensitizer pioglitazone on insulin resistance, hyperandrogenism, and ovulatory dysfunction in women with polycystic ovary syndrome," Journal of Clinical Endocrinology and Metabolism, vol. 89, no. 8, pp. 3835-3840, 2004.

[96] S. H. Belli, M. N. Graffigna, A. Oneto, P. Otero, L. Schurman, and O. A. Levalle, "Effect of rosiglitazone on insulin resistance, growth factors, and reproductive disturbances in women with polycystic ovary syndrome," Fertility and Sterility, vol. 81, no. 3, pp. 624-629, 2004.

[97] A. Shobokshi and M. Shaarawy, "Correction of insulin resistance and hyperandrogenism in polycystic ovary syndrome by combined rosiglitazone and clomiphene citrate therapy," Journal of the Society for Gynecologic Investigation, vol. 10, no. 2, pp. 99-104, 2003.

[98] D. Seto-Young, M. Paliou, J. Schlosser, et al., "Direct thiazolidinedione action in the human ovary: insulin-independent and insulin-sensitizing effects on steroidogenesis and insulinlike growth factor binding protein-1 production," Journal of Clinical Endocrinology and Metabolism, vol. 90, no. 11, pp. 6099-6105, 2005.

[99] S. Gasic, M. Nagamani, A. Green, and R. J. Urban, "Troglitazone is a competitive inhibitor of $3 \beta$-hydroxysteroid dehydrogenase enzyme in the ovary," American Journal of Obstetrics and Gynecology, vol. 184, no. 4, pp. 575-579, 2001.

[100] M. S. Coffler, K. Patel, M. H. Dahan, R. Y. Yoo, P. J. Malcom, and R. J. Chang, "Enhanced granulosa cell responsiveness to follicle-stimulating hormone during insulin infusion in women with polycystic ovary syndrome treated with pioglitazone," Journal of Clinical Endocrinology and Metabolism, vol. 88, no. 12, pp. 5624-5631, 2003.

[101] C. E. Minge, B. D. Bennett, M. Lane, R. J. Norman, and R. L. Robker, "Obesity-induced female infertility arises from impaired oocyte developmental competence and can be reversed by peri-ovulatory rosiglitazone treatment," in Proceedings of the 10th International Congress on Obesity, Sydney, Australia, 2006.

[102] W. L. Miller, "Steroidogenic acute regulatory protein (StAR), a novel mitochondrial cholesterol transporter," Biochimica et Biophysica Acta-Molecular and Cell Biology of Lipids, vol. 1771, no. 6, pp. 663-676, 2007.

[103] D. Seto-Young, D. Avtanski, M. Strizhevsky, et al., "Interactions among peroxisome proliferator activated receptor- $\gamma$, insulin signaling pathways, and steroidogenic acute regulatory protein in human ovarian cells," Journal of Clinical Endocrinology and Metabolism, vol. 92, no. 6, pp. 2232-2239, 2007.

[104] W. C. Duncan, G. M. Cowen, and P. J. Illingworth, "Steroidogenic enzyme expression in human corpora lutea in the presence and absence of exogenous human chorionic gonadotrophin (HCG)," Molecular Human Reproduction, vol. 5, no. 4, pp. 291-298, 1999.

[105] K. J. Doody, M. C. Lorence, J. I. Mason, and E. R. Simpson, "Expression of messenger ribonucleic acid species encoding steroidogenic enzymes in human follicles and corpora lutea throughout the menstrual cycle," Journal of Clinical Endocrinology and Metabolism, vol. 70, no. 4, pp. 1041-1045, 1990.
[106] W. Arlt, R. J. Auchus, and W. L. Miller, "Thiazolidinediones but not metformin directly inhibit the steroidogenic enzymes P450c17 and $3 \beta$-hydroxysteroid dehydrogenase," Journal of Biological Chemistry, vol. 276, no. 20, pp. 16767-16771, 2001.

[107] P. Kempná, G. Hofer, P. E. Mullis, and C. E. Flück, "Pioglitazone inhibits androgen production in NCI-H295R cells by regulating gene expression of CYP17 and HSD3B2," Molecular Pharmacology, vol. 71, no. 3, pp. 787-798, 2007.

[108] J. D. Veldhuis, G. Zhang, and J. C. Garmey, "Troglitazone, an insulin-sensitizing thiazolidinedione, represses combined stimulation by LH and insulin of de novo androgen biosynthesis by thecal cells in vitro," Journal of Clinical Endocrinology and Metabolism, vol. 87, no. 3, pp. 1129-1133, 2002.

[109] M. P. Steinkampf, C. R. Mendelson, and E. R. Simpson, "Regulation by follicle-stimulating hormone of the synthesis of aromatase cytochrome P-450 in human granulosa cells," Molecular Endocrinology, vol. 1, no. 7, pp. 465-471, 1987.

[110] J. S. Krasnow, G. J. Hickey, and J. S. Richards, "Regulation of aromatase mRNA and estradiol biosynthesis in rat ovarian granulosa and luteal cells by prolactin," Molecular Endocrinology, vol. 4, no. 1, pp. 13-21, 1990.

[111] T. Yanase, Y.-M. Mu, Y. Nishi, et al., "Regulation of aromatase by nuclear receptors," Journal of Steroid Biochemistry and Molecular Biology, vol. 79, no. 1-5, pp. 187-192, 2001.

[112] Y.-M. Mu, T. Yanase, Y. Nishi, R. Takayanagi, K. Goto, and H. Nawata, "Combined treatment with specific ligands for $\operatorname{PPAR} \gamma: \operatorname{RXR}$ nuclear receptor system markedly inhibits the expression of cytochrome P450arom in human granulosa cancer cells," Molecular and Cellular Endocrinology, vol. 181, no. 1-2, pp. 239-248, 2001.

[113] W. Fan, T. Yanase, H. Morinaga, et al., "Activation of peroxisome proliferator-activated receptor- $\gamma$ and retinoid $\mathrm{X}$ receptor inhibits aromatase transcription via nuclear factor- $\kappa \mathrm{B}$," Endocrinology, vol. 146, no. 1, pp. 85-92, 2005.

[114] J.-P. Baillargeon, D. J. Jakubowicz, M. J. Iuorno, S. Jakubowicz, and J. E. Nestler, "Effects of metformin and rosiglitazone, alone and in combination, in nonobese women with polycystic ovary syndrome and normal indices of insulin sensitivity," Fertility and Sterility, vol. 82, no. 4, pp. 893-902, 2004.

[115] D. Romualdi, M. Guido, M. Ciampelli, et al., "Selective effects of pioglitazone on insulin and androgen abnormalities in normo- and hyperinsulinaemic obese patients with polycystic ovary syndrome," Human Reproduction, vol. 18, no. 6, pp. 1210-1218, 2003.

[116] T. Lovekamp-Swan, A. M. Jetten, and B. J. Davis, "Dual activation of PPAR $\alpha$ and PPAR $\gamma$ by mono-(2-ethylhexyl) phthalate in rat ovarian granulosa cells," Molecular and Cellular Endocrinology, vol. 201, no. 1-2, pp. 133-141, 2003.

[117] A. Rubenstrunk, R. Hanf, D. W. Hum, J.-C. Fruchart, and B. Staels, "Safety issues and prospects for future generations of PPAR modulators," Biochimica et Biophysica Acta-Molecular and Cell Biology of Lipids, vol. 1771, no. 8, pp. 1065-1081, 2007.

[118] A. V. Schwartz, D. E. Sellmeyer, E. Vittinghoff, et al., "Thiazolidinedione use and bone loss in older diabetic adults," Journal of Clinical Endocrinology and Metabolism, vol. 91, no. 9, pp. 3349-3354, 2006.

[119] D. B. Klinkner, H. J. Lim, E. Y. Strawn Jr., K. T. Oldham, and T. L. Sander, "An in vivo murine model of rosiglitazone use in pregnancy," Fertility and Sterility, vol. 86, no. 4, pp. 10741079, 2006.

[120] N. A. Cataldo, F. Abbasi, T. L. McLaughlin, C. Lamendola, and G. M. Reaven, "Improvement in insulin sensitivity followed by ovulation and pregnancy in a woman 
with polycystic ovary syndrome who was treated with rosiglitazone," Fertility and Sterility, vol. 76, no. 5, pp. 10571059, 2001.

[121] L. Y.-S. Chan, J. H.-K. Yeung, and T. K. Lau, "Placental transfer of rosiglitazone in the first trimester of human pregnancy," Fertility and Sterility, vol. 83, no. 4, pp. 955-958, 2005.

[122] A. Dunaif, "Insulin action in the polycystic ovary syndrome," Endocrinology and Metabolism Clinics of North America, vol. 28, no. 2, pp. 341-359, 1999.

[123] L. Poretsky, J. Clemons, and K. Bogovich, "Hyperinsulinemia and human chorionic gonadotropin synergistically promote the growth of ovarian follicular cysts in rats," Metabolism, vol. 41, no. 8, pp. 903-910, 1992.

[124] N. K. Kuşcu, F. Koyuncu, K. Özbilgin, S. Inan, I. Tuğlu, and Ö. Karaer, "Insulin: does it induce follicular arrest in the rat ovary?” Gynecological Endocrinology, vol. 16, no. 5, pp. 361364, 2002.

[125] S. Hashimoto, N. Minami, M. Yamada, and H. Imai, "Excessive concentration of glucose during in vitro maturation impairs the developmental competence of bovine oocytes after in vitro fertilization: relevance to intracellular reactive oxygen species and glutathione contents," Molecular Reproduction and Development, vol. 56, no. 4, pp. 520-526, 2000.

[126] S. A. Colton, G. M. Pieper, and S. M. Downs, "Altered meiotic regulation in oocytes from diabetic mice," Biology of Reproduction, vol. 67, no. 1, pp. 220-231, 2002.

[127] J. Rieusset, J. Auwerx, and H. Vidal, "Regulation of gene expression by activation of the peroxisome proliferatoractivated receptor $\gamma$ with rosiglitazone (BRL 49653) in human adipocytes," Biochemical and Biophysical Research Communications, vol. 265, no. 1, pp. 265-271, 1999.

[128] U. Smith, S. Gogg, A. Johansson, T. Olausson, V. Rotter, and B. Svalstedt, "Thiazolidinediones (PPAR $\gamma$ agonists) but not PPAR $\alpha$ agonists increase IRS-2 gene expression in 3T3-L1 and human adipocytes," FASEB Journal, vol. 15, no. 1, pp. 215-220, 2001.

[129] T. P. Ciaraldi, A. P. S. Kong, N. V. Chu, et al., "Regulation of glucose transport and insulin signaling by troglitazone or metformin in adipose tissue of type 2 diabetic subjects," $D i$ abetes, vol. 51, no. 1, pp. 30-36, 2002.

[130] L. M. Furtado, V. Poon, and A. Klip, "GLUT4 activation: thoughts on possible mechanisms," Acta Physiologica Scandinavica, vol. 178, no. 4, pp. 287-296, 2003.

[131] N. Khandoudi, P. Delerive, I. Berrebi-Bertrand, R. E. Buckingham, B. Staels, and A. Bril, "Rosiglitazone, a peroxisome proliferator-activated receptor- $\gamma$, inhibits the Jun NH2terminal kinase/activating protein 1 pathway and protects the heart from ischemia/reperfusion injury," Diabetes, vol. 51, no. 5, pp. 1507-1514, 2002.

[132] G. Jiang, Q. Dallas-Yang, S. Biswas, Z. Li, and B. B. Zhang, "Rosiglitazone, an agonist of peroxisomeproliferator-activated receptor $\gamma(\operatorname{PPAR} \gamma)$, decreases inhibitory serine phosphorylation of IRS1 in vitro and in vivo," Biochemical Journal, vol. 377, no. 2, pp. 339-346, 2004.

[133] G. Jiang and B. B. Zhang, "Modulation of insulin signalling by insulin sensitizers," Biochemical Society Transactions, vol. 33, no. 2, pp. 358-361, 2005.

[134] L. Guo and R. Tabrizchi, "Peroxisome proliferator-activated receptor gamma as a drug target in the pathogenesis of insulin resistance," Pharmacology and Therapeutics, vol. 111, no. 1, pp. 145-173, 2006.
[135] S.-Y. Ku, S. D. Kim, B. C. Jee, et al., "Clinical efficacy of body mass index as predictor of in vitro fertilization and embryo transfer outcomes," Journal of Korean Medical Science, vol. 21, no. 2, pp. 300-303, 2006.

[136] A. Bongain, V. Isnard, and J.-Y. Gillet, "Obesity in obstetrics and gynaecology," European Journal of Obstetrics Gynecology and Reproductive Biology, vol. 77, no. 2, pp. 217-228, 1998.

[137] Y. Linné, "Effects of obesity on women's reproduction and complications during pregnancy," Obesity Reviews, vol. 5, no. 3, pp. 137-143, 2004.

[138] G. A. Bray, "Obesity and reproduction," Human Reproduction, vol. 12, no. 1, pp. 26-32, 1997.

[139] J. X. Wang, M. Davies, and R. J. Norman, "Body mass and probability of pregnancy during assisted reproduction treatment: retrospective study," British Medical Journal, vol. 321, no. 7272, pp. 1320-1321, 2000.

[140] R. Pasquali, C. Pelusi, S. Genghini, M. Cacciari, and A. Gambineri, "Obesity and reproductive disorders in women," $\mathrm{Hu}$ man Reproduction Update, vol. 9, no. 4, pp. 359-372, 2003.

[141] B. M. Zaadstra, J. C. Seidell, P. A. H. Van Noord, et al., "Fat and female fecundity: prospective study of effect of body fat distribution on conception rates," British Medical Journal, vol. 306, no. 6876, pp. 484-487, 1993.

[142] A. Fukuhara, M. Matsuda, M. Nishizawa, et al., "Visfatin: a protein secreted by visceral fat that mimics the effects of insulin," Science, vol. 307, no. 5708, pp. 426-430, 2005.

[143] T. E. Graham, Q. Yang, M. Blüher, et al., "Retinol-binding protein 4 and insulin resistance in lean, obese, and diabetic subjects," New England Journal of Medicine, vol. 354, no. 24, pp. 2552-2563, 2006.

[144] B. K. Tan, J. Chen, J. E. Digby, S. D. Keay, C. R. Kennedy, and H. S. Randeva, "Increased visfatin messenger ribonucleic acid and protein levels in adipose tissue and adipocytes in women with polycystic ovary syndrome: parallel increase in plasma visfatin," Journal of Clinical Endocrinology and Metabolism, vol. 91, no. 12, pp. 5022-5028, 2006.

[145] B. K. Tan, J. Chen, H. Lehnert, R. Kennedy, and H. S. Randeva, "Raised serum, adipocyte, and adipose tissue retinolbinding protein 4 in overweight women with polycystic ovary syndrome: effects of gonadal and adrenal steroids," Journal of Clinical Endocrinology and Metabolism, vol. 92, no. 7, pp. 2764-2772, 2007.

[146] M. Iwaki, M. Matsuda, N. Maeda, et al., "Induction of adiponectin, a fat-derived antidiabetic and antiatherogenic factor, by nuclear receptors," Diabetes, vol. 52, no. 7, pp. 1655-1663, 2003.

[147] P. De Vos, A.-M. Lefebvre, S. G. Miller, et al., "Thiazolidinediones repress ob gene expression in rodents via activation of peroxisome proliferator-activated receptor $\gamma$," Journal of Clinical Investigation, vol. 98, no. 4, pp. 1004-1009, 1996.

[148] D. Sinha, S. Addya, E. Murer, and G. Boden, "15-Deoxy- $\Delta^{12,14}$ prostaglandin J2: a putative endogenous promoter of adipogenesis suppresses the ob gene," Metabolism, vol. 48, no. 6, pp. 786-791, 1999.

[149] C. B. Kallen and M. A. Lazar, "Antidiabetic thiazolidinediones inhibit leptin $(o b)$ gene expression in 3T3-L1 adipocytes," Proceedings of the National Academy of Sciences of the United States of America, vol. 93, no. 12, pp. 5793-5796, 1996.

[150] Y. Miyazaki, A. Mahankali, E. Wajcberg, M. Bajaj, L. J. Mandarino, and R. A. DeFronzo, "Effect of pioglitazone on circulating adipocytokine levels and insulin sensitivity in type 2 diabetic patients," Journal of Clinical Endocrinology and Metabolism, vol. 89, no. 9, pp. 4312-4319, 2004. 
[151] C. Otto, B. Otto, B. Göke, et al., "Increase in adiponectin levels during pioglitazone therapy in relation to glucose control, insulin resistance as well as ghrelin and resistin levels," Journal of Endocrinological Investigation, vol. 29, no. 3, pp. 231236, 2006.

[152] L. J. Spicer and C. C. Francisco, "The adipose obese gene product, leptin: evidence of a direct inhibitory role in ovarian function," Endocrinology, vol. 138, no. 8, pp. 3374-3379, 1997.

[153] C. Karlsson, K. Lindell, E. Svensson, et al., "Expression of functional leptin receptors in the human ovary," Journal of Clinical Endocrinology and Metabolism, vol. 82, no. 12, pp. 4144-4148, 1997.

[154] N. K. Ryan, K. H. Van der Hoek, S. A. Robertson, and R. J. Norman, "Leptin and leptin receptor expression in the rat ovary," Endocrinology, vol. 144, no. 11, pp. 5006-5013, 2003.

[155] R. J. Zachow and D. A. Magoffin, "Direct intraovarian effects of leptin: impairment of the synergistic action of insulin-like growth factor-I on follicle-stimulating hormone- dependent estradiol-17 $\beta$ production by rat ovarian granulosa cells," Endocrinology, vol. 138, no. 2, pp. 847-850, 1997.

[156] N. K. Ryan, C. M. Woodhouse, K. H. Van der Hoek, R. B. Gilchrist, D. T. Armstrong, and R. J. Norman, "Expression of leptin and its receptor in the murine ovary: possible role in the regulation of oocyte maturation," Biology of Reproduction, vol. 66, no. 5, pp. 1548-1554, 2002.

[157] J. E. Swain, R. L. Dunn, D. McConnell, J. Gonzalez-Martinez, and G. D. Smith, "Direct effects of leptin on mouse reproductive function: regulation of follicular, oocyte, and embryo development," Biology of Reproduction, vol. 71, no. 5, pp. 14461452, 2004.

[158] E. Lord, S. Ledoux, B. D. Murphy, D. Beaudry, and M. F. Palin, "Expression of adiponectin and its receptors in swine," Journal of Animal Science, vol. 83, no. 3, pp. 565-578, 2005.

[159] S. Ledoux, D. B. Campos, F. L. Lopes, M. Dobias-Goff, M.-F. Palin, and B. D. Murphy, "Adiponectin induces periovulatory changes in ovarian follicular cells," Endocrinology, vol. 147, no. 11, pp. 5178-5186, 2006.

[160] P. Tontonoz, E. Hu, J. Devine, E. G. Beale, and B. M. Spiegelman, "PPAR $\gamma 2$ regulates adipose expression of the phosphoenolpyruvate carboxykinase gene," Molecular and Cellular Biology, vol. 15, no. 1, pp. 351-357, 1995.

[161] K. Schoonjans, J. Peinado-Onsurbe, A.-M. Lefebvre, et al., "PPAR $\alpha$ and PPAR $\gamma$ activators direct a distinct tissue-specific transcriptional response via a PPRE in the lipoprotein lipase gene," EMBO Journal, vol. 15, no. 19, pp. 5336-5348, 1996.

[162] S. R. Ross, R. A. Graves, A. Greenstein, et al., "A fat-specific enhancer is the primary determinant of gene expression for adipocyte P2 in vivo," Proceedings of the National Academy of Sciences of the United States of America, vol. 87, no. 24, pp. 9590-9594, 1990.

[163] M. Watanabe, K. Inukai, H. Katagiri, T. Awata, Y. Oka, and S. Katayama, "Regulation of PPAR $y$ transcriptional activity in 3T3-L1 adipocytes," Biochemical and Biophysical Research Communications, vol. 300, no. 2, pp. 429-436, 2003.

[164] P. Tontonoz, L. Nagy, J. G. A. Alvarez, V. A. Thomazy, and R. M. Evans, "PPAR $\gamma$ promotes monocyte/macrophage differentiation and uptake of oxidized LDL," Cell, vol. 93, no. 2, pp. 241-252, 1998.

[165] G. Chinetti, F. G. Gbaguidi, S. Griglio, et al., "CLA-1/SR-BI is expressed in atherosclerotic lesion macrophages and regulated by activators of peroxisome proliferator-activated receptors," Circulation, vol. 101, no. 20, pp. 2411-2417, 2000.
[166] J. J. Petrik, P. A. Gentry, J.-J. Feige, and J. LaMarre, "Expression and localization of thrombospondin-1 and -2 and their cell-surface receptor, CD36, during rat follicular development and formation of the corpus luteum," Biology of Reproduction, vol. 67, no. 5, pp. 1522-1531, 2002.

[167] J. Greenaway, P. A. Gentry, J.-J. Feige, J. LaMarre, and J. J. Petrik, "Thrombospondin and vascular endothelial growth factor are cyclically expressed in an inverse pattern during bovine ovarian follicle development," Biology of Reproduction, vol. 72, no. 5, pp. 1071-1078, 2005.

[168] J. E. Murphy-Ullrich, "The de-adhesive activity of matricellular proteins: is intermediate cell adhesion an adaptive state?" Journal of Clinical Investigation, vol. 107, no. 7, pp. 785-790, 2001.

[169] S. Goicoechea, A. W. Orr, M. A. Pallero, P. Eggleton, and J. E. Murphy-Ullrich, "Thrombospondin mediates focal adhesion disassembly through interactions with cell surface calreticulin," Journal of Biological Chemistry, vol. 275, no. 46, pp. 36358-36368, 2000.

[170] L. Nagy, P. Tontonoz, J. G. A. Alvarez, H. Chen, and R. M. Evans, "Oxidized LDL regulates macrophage gene expression through ligand activation of PPAR $\gamma$," Cell, vol. 93, no. 2, pp. 229-240, 1998.

[171] M. Ricote, J. T. Huang, J. S. Welch, and C. K. Glass, “The peroxisome proliferator-activated receptor $\gamma(\operatorname{PPAR} \gamma)$ as a regulator of monocyte/macrophage function," Journal of Leukocyte Biology, vol. 66, no. 5, pp. 733-739, 1999.

[172] P.-A. Svensson, M. S. C. Johnson, C. Ling, L. M. S. Carlsson, H. Billig, and B. Carlsson, "Scavenger receptor class B type I in the rat ovary: possible role in high density lipoprotein cholesterol uptake and in the recognition of apoptotic granulosa cells," Endocrinology, vol. 140, no. 6, pp. 2494-2500, 1999.

[173] E. Reaven, A. Nomoto, S. Leers-Sucheta, R. Temel, D. L. Williams, and S. Azhar, "Expression and microvillar localization of scavenger receptor, class B, type I (a high density lipoprotein receptor) in luteinized and hormone- desensitized rat ovarian models," Endocrinology, vol. 139, no. 6, pp. 2847-2856, 1998.

[174] M. Ricote, J. Huang, L. Fajas, et al., "Expression of the peroxisome proliferator-activated receptor $\gamma(\operatorname{PPAR} \gamma)$ in human atherosclerosis and regulation in macrophages by colony stimulating factors and oxidized low density lipoprotein," Proceedings of the National Academy of Sciences of the United States of America, vol. 95, no. 13, pp. 7614-7619, 1998.

[175] M. Ricote, A. C. Li, T. M. Willson, C. J. Kelly, and C. K. Glass, "The peroxisome proliferator-activated receptor- $\gamma$ is a negative regulator of macrophage activation," Nature, vol. 391, no. 6662, pp. 79-82, 1998.

[176] R. B. Clark, D. Bishop-Bailey, T. Estrada-Hernandez, T. Hla, L. Puddington, and S. J. Padula, "The nuclear receptor PPAR $\gamma$ and immunoregulation: PPAR $\gamma$ mediates inhibition of helper T cell responses," Journal of Immunology, vol. 164, no. 3, pp. 1364-1371, 2000.

[177] Y. Azuma, M. Shinohara, P.-L. Wang, and K. Ohura, "15deoxy- $\Delta^{12,14}$-prostaglandin $\mathrm{J}_{2}$ inhibits IL-10 and IL-12 production by macrophages," Biochemical and Biophysical Research Communications, vol. 283, no. 2, pp. 344-346, 2001.

[178] P. Wang, P. O. Anderson, S. Chen, K. M. Paulsson, H.-O. Sjögren, and S. Li, "Inhibition of the transcription factors $\mathrm{AP}-1$ and NF- $\kappa \mathrm{B}$ in CD4 $\mathrm{T}$ cells by peroxisome proliferatoractivated receptor $\gamma$ ligands," International Immunopharmacology, vol. 1, no. 4, pp. 803-812, 2001. 
[179] D. G. Alleva, E. B. Johnson, F. M. Lio, S. A. Boehme, P. J. Conlon, and P. D. Crowe, "Regulation of murine macrophage proinflammatory and anti-inflammatory cytokines by ligands for peroxisome proliferator-activated receptor- $\gamma$ : counter-regulatory activity by IFN- $\gamma$," Journal of Leukocyte Biology, vol. 71, no. 4, pp. 677-685, 2002.

[180] M. Okada, S. F. Yan, and D. J. Pinsky, "Peroxisome proliferator-activated receptor- $\gamma$ (PPAR- $\gamma$ ) activation suppresses ischemic induction of Egr-1 and its inflammatory gene targets," FASEB Journal, vol. 16, no. 14, pp. 1861-1868, 2002.

[181] B. Hinz, K. Brune, and A. Pahl, "15-deoxy- $\Delta^{12,14}$ prostaglandin $\mathrm{J}_{2}$ inhibits the expression of proinflammatory genes in human blood monocytes via a PPAR- $\gamma$-independent mechanism," Biochemical and Biophysical Research Communications, vol. 302, no. 2, pp. 415-420, 2003.

[182] K. Asada, S. Sasaki, T. Suda, K. Chida, and H. Nakamura, "Antiinflammatory roles of peroxisome proliferatoractivated receptor $\gamma$ in human alveolar macrophages," American Journal of Respiratory and Critical Care Medicine, vol. 169, no. 2, pp. 195-200, 2004.

[183] G. Chinetti, J.-C. Fruchart, and B. Staels, "Peroxisome proliferator-activated receptors (PPARs): nuclear receptors at the crossroads between lipid metabolism and inflammation," Inflammation Research, vol. 49, no. 10, pp. 497-505, 2000.

[184] P. Delerive, J.-C. Fruchart, and B. Staels, "Peroxisome proliferator-activated receptors in inflammation control," Journal of Endocrinology, vol. 169, no. 3, pp. 453-459, 2001.

[185] P. Henson, "Suppression of macrophage inflammatory responses by PPARs," Proceedings of the National Academy of Sciences of the United States of America, vol. 100, no. 11, pp. 6295-6296, 2003.

[186] B. Zahorska-Markiewicz, J. Janowska, M. OlszaneckaGlinianowicz, and A. Zurakowski, "Serum concentrations of TNF- $\alpha$ and soluble TNF- $\alpha$ receptors in obesity," International Journal of Obesity, vol. 24, no. 11, pp. 1392-1395, 2000.

[187] M. Olszanecka-Glinianowicz, B. Zahorska-Markiewicz, J. Janowska, and A. Zurakowski, "Serum concentrations of nitric oxide, tumor necrosis factor (TNF)- $\alpha$ and TNF soluble receptors in women with overweight and obesity," Metabolism: Clinical and Experimental, vol. 53, no. 10, pp. 1268-1273, 2004.

[188] G. S. Hotamisligil, N. S. Shargill, and B. M. Spiegelman, "Adipose expression of tumor necrosis factor- $\alpha$ : direct role in obesity-linked insulin resistance," Science, vol. 259, no. 5091, pp. 87-91, 1993.

[189] J. M. Stephens, J. Lee, and P. F. Pilch, “Tumor necrosis factor$\alpha$-induced insulin resistance in 3T3-L1 adipocytes is accompanied by a loss of insulin receptor substrate-1 and GLUT4 expression without a loss of insulin receptor-mediated signal transduction," Journal of Biological Chemistry, vol. 272, no. 2, pp. 971-976, 1997.

[190] G. Kroder, B. Bossenmaier, M. Kellerer, et al., "Tumor necrosis factor- $\alpha$ - and hyperglycemia-induced insulin resistance: evidence for different mechanisms and different effects on insulin signaling," Journal of Clinical Investigation, vol. 97, no. 6, pp. 1471-1477, 1996.

[191] J. S. Yudkin, M. Kumari, S. E. Humphries, and V. MohamedAli, "Inflammation, obesity, stress and coronary heart disease: is interleukin-6 the link?" Atherosclerosis, vol. 148, no. 2, pp. 209-214, 2000.

[192] M. Olszanecka-Glinianowicz, M. Banaś, B. ZahorskaMarkiewicz, et al., "Is the polycystic ovary syndrome associated with chronic inflammation per se?” European Journal of Obstetrics Gynecology and Reproductive Biology, vol. 133, no. 2, pp. 197-202, 2007.

[193] Y.-F. Zhang, Y.-S. Yang, J. Hong, et al., "Elevated serum levels of interleukin-18 are associated with insulin resistance in women with polycystic ovary syndrome," Endocrine, vol. 29, no. 3, pp. 419-423, 2006.

[194] P. O. Szapary, L. T. Bloedon, F. F. Samaha, et al., "Effects of pioglitazone on lipoproteins, inflammatory markers, and adipokines in nondiabetic patients with metabolic syndrome," Arteriosclerosis, Thrombosis, and Vascular Biology, vol. 26, no. 1, pp. 182-188, 2006.

[195] F. F. Samaha, P. O. Szapary, N. Iqbal, et al., "Effects of rosiglitazone on lipids, adipokines, and inflammatory markers in nondiabetic patients with low high-density lipoprotein cholesterol and metabolic syndrome," Arteriosclerosis, Thrombosis, and Vascular Biology, vol. 26, no. 3, pp. 624-630, 2006.

[196] K. Esposito, M. Ciotola, D. Carleo, et al., "Effect of rosiglitazone on endothelial function and inflammatory markers in patients with the metabolic syndrome," Diabetes Care, vol. 29, no. 5, pp. 1071-1076, 2006.

[197] T.-D. Wang, W.-J. Chen, J.-W. Lin, M.-F. Chen, and Y.-T. Lee, "Effects of Rosiglitazone on endothelial function, C-reactive protein, and components of the metabolic syndrome in nondiabetic patients with the metabolic syndrome," American Journal of Cardiology, vol. 93, no. 3, pp. 362-365, 2004.

[198] T.-D. Wang, W.-J. Chen, W.-C. Cheng, J.-W. Lin, M.-F. Chen, and Y.-T. Lee, "Relation of improvement in endotheliumdependent flow-mediated vasodilation after rosiglitazone to changes in asymmetric dimethylarginine, endothelin-1, and C-reactive protein in nondiabetic patients with the metabolic syndrome," American Journal of Cardiology, vol. 98, no. 8, pp. 1057-1062, 2006.

[199] P. Hellberg, P. Thomsen, P. O. Janson, and M. Brannstrom, "Leukocyte supplementation increases the luteinizing hormone-induced ovulation rate in the in vitro-perfused rat ovary," Biology of Reproduction, vol. 44, no. 5, pp. 791-797, 1991.

[200] M. Brannstrom, G. Mayrhofer, and S. A. Robertson, "Localization of leukocyte subsets in the rat ovary during the periovulatory period," Biology of Reproduction, vol. 48, no. 2, pp. 277-286, 1993.

[201] K. H. Van der Hoek, S. Maddocks, C. M. Woodhouse, N. Van Rooijen, S. A. Robertson, and R. J. Norman, "Intrabursal injection of clodronate liposomes causes macrophage depletion and inhibits ovulation in the mouse ovary," Biology of Reproduction, vol. 62, no. 4, pp. 1059-1066, 2000.

[202] P. E. Cohen, K. Nishimura, L. Zhu, and J. W. Pollard, "Macrophages: important accessory cells for reproductive function," Journal of Leukocyte Biology, vol. 66, no. 5, pp. 765772, 1999.

[203] M. Brännström and P. O. Janson, "The biochemistry of ovulation," in Ovarian Endocrinology, pp. 133-166, Blackwell Science, Oxford, UK, 1991.

[204] R. Takaya, T. Fukaya, H. Sasano, T. Suzuki, M. Tamura, and A. Yajima, "Macrophages in normal cycling human ovaries; immunohistochemical localization and characterization," $\mathrm{Hu}$ man Reproduction, vol. 12, no. 7, pp. 1508-1512, 1997.

[205] E. Y. Anteby, A. Hurwitz, O. Korach, et al., "Human follicular nitric oxide pathway: relationship to follicular size, oestradiol concentrations and ovarian blood flow," Human Reproduction, vol. 11, no. 9, pp. 1947-1951, 1996. 
[206] C. Battaglia, M. Salvatori, N. Maxia, F. Petraglia, F. Facchinetti, and A. Volpe, "Adjuvant L-arginine treatment for in-vitro fertilization in poor responder patients," Human Reproduction, vol. 14, no. 7, pp. 1690-1697, 1999.

[207] D. G. Lemay and D. H. Hwang, "Genome-wide identification of peroxisome proliferator response elements using integrated computational genomics," Journal of Lipid Research, vol. 47, no. 7, pp. 1583-1587, 2006. 


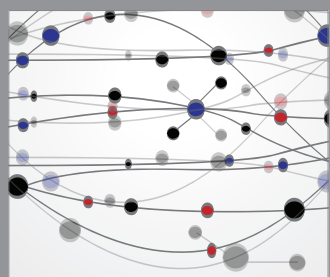

The Scientific World Journal
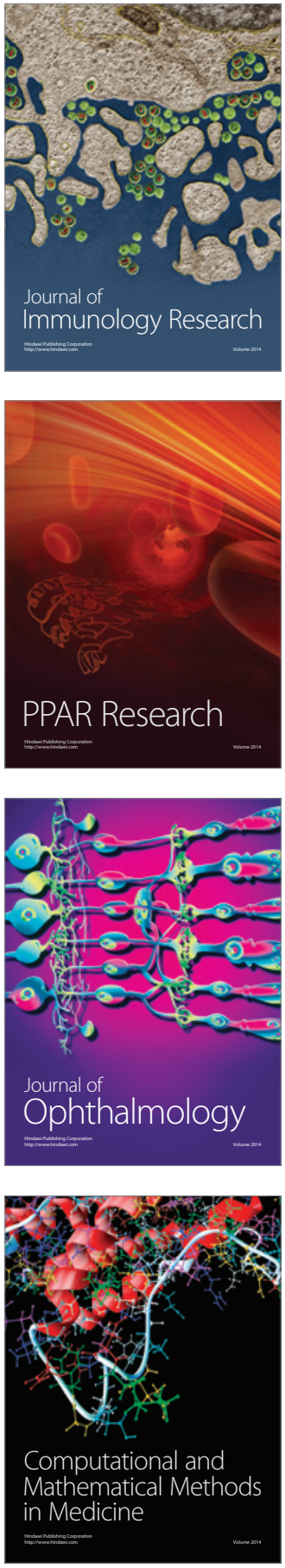

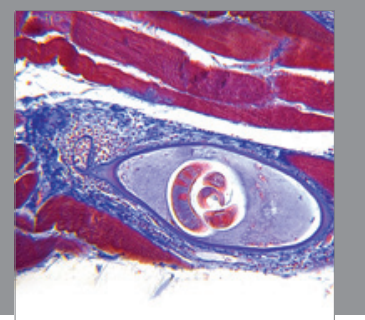

Gastroenterology

Research and Practice
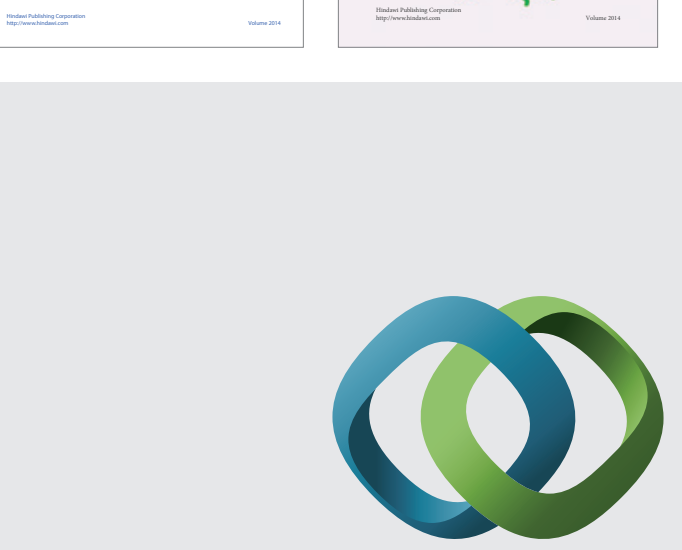

\section{Hindawi}

Submit your manuscripts at

http://www.hindawi.com
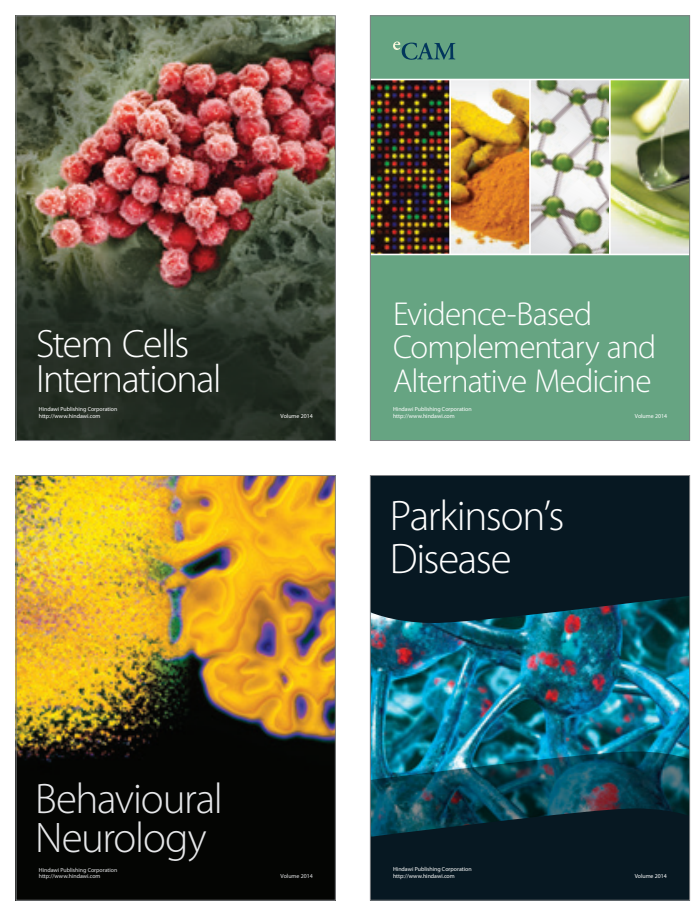

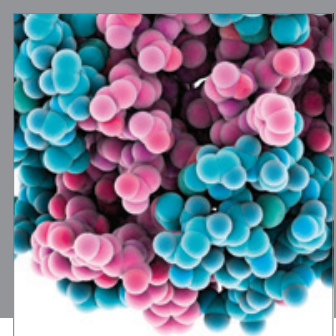

Journal of
Diabetes Research

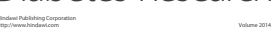

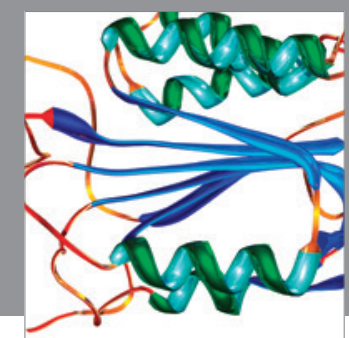

Disease Markers
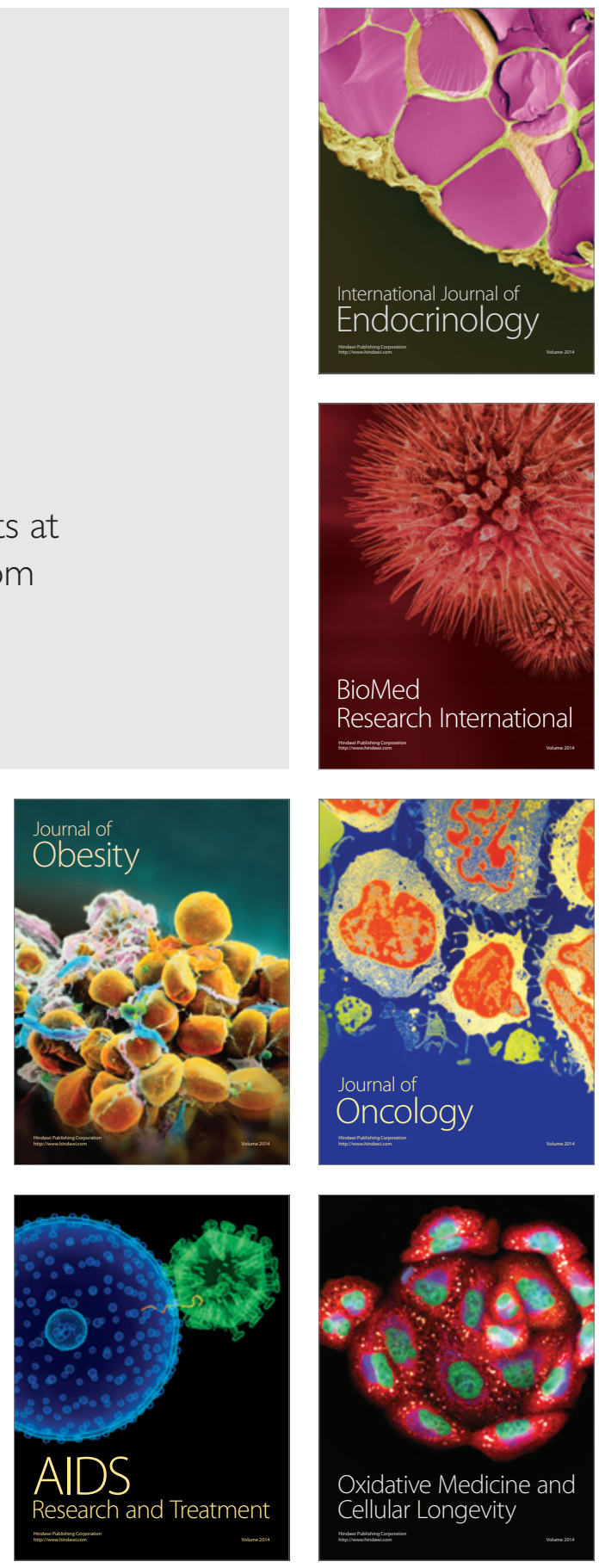